Pineda Nicolau (Orcid ID: 0000-0002-2507-8424)

Figueras i Ventura Jordi (Orcid ID: 0000-0002-4949-422X)

Mostajabi Amirhossein (Orcid ID: 0000-0001-7644-2348)

Azadifar Mohammad (Orcid ID: 0000-0002-0489-1838)

Sunjerga Antonio (Orcid ID: 0000-0001-8167-6296)

Rachidi Farhad (Orcid ID: 0000-0002-2169-9549)

Rubinstein Marcos (Orcid ID: 0000-0003-4806-038X)

Montanya Joan (Orcid ID: 0000-0003-2488-697X)

van der Velde Oscar, A. (Orcid ID: 0000-0002-1638-6628)

grazioli jacopo (Orcid ID: 0000-0002-7097-3946)

Williams Earle, R. (Orcid ID: 0000-0003-1488-3361)

\title{
Meteorological aspects of self-initiated upward lightning at the Säntis tower (Switzerland)
}

Nicolau Pineda ${ }^{1,2 *}$, Jordi Figueras i Ventura ${ }^{3}$, David Romero², Amirhossein Mostajabi ${ }^{4}$, Mohammad Azadifar ${ }^{5}$, Antonio Sunjerga ${ }^{4}$, Farhad Rachidi ${ }^{4}$, Marcos Rubinstein ${ }^{5}$, Joan Montanyà $^{2}$, Oscar van der Velde ${ }^{2}$, Patricia Altube ${ }^{1}$, Nikola Besic ${ }^{3,6}$, Jacopo Grazioli ${ }^{3}$, Urs Germann $^{3}$, Earle R. Williams ${ }^{7}$

${ }^{1}$ Remote Sensing Unit, Meteorological Service of Catalonia, Barcelona, Spain

${ }^{2}$ Lightning Research Group, Technical University of Catalonia, Terrassa 08222, Spain

${ }^{3}$ Radar, Satellite and Nowcasting Division, MeteoSwiss, Locarno-Monti, Switzerland

${ }^{4}$ Electromagnetic Caompatibility Laboratory, Swiss Federal Institute of Technology,

Lausanne, Switzerland

${ }^{5}$ Institute for Information and Communication Technologies, University of Applied Sciences of Western Switzerland, Yverdon-les-Bains, Switzerland

${ }^{6}$ Environmental Remote Sensing Laboratory, Swiss Federal Institute of Technology,

Lausanne, Lausanne, Switzerland

${ }^{7}$ Massachusetts Institute of Technology, Cambridge, Massachusetts, 02139 USA

Corresponding author: Nicolau Pineda (nicolau.pineda@gencat.cat)

\section{Key Points:}

- After a short vertical path, upward positive leaders turned horizontal to spread above the melting level

- Self-initiated upward lightning occurred under stratiform precipitation, once the convective region of the system has passed away

This article has been accepted for publication and undergone full peer review but has not been through the copyediting, typesetting, pagination and proofreading process which may lead to differences between this version and the Version of Record. Please cite this article as doi: 10.1029/2019JD030834 
- A key feature favoring self-initiated upward lightning is the proximity of the tower tip to the melting level

\begin{abstract}
Interest in exploring the meteorological conditions favoring upward lightning from tall man-made structures has grown in recent years, largely due to the worldwide expansion of wind energy. To this end, instrumented towers existing around the world are the most suitable places to study upward lightning. In this context, an LMA network was deployed around the Säntis Mountain (northeast Switzerland) during the summer of 2017, in order to complement the long-term measurements currently held at the Säntis telecommunications tower, a lightning hotspot in Central Europe. This campaign allowed, for the first time, to gather a comprehensive set of observations of self-initiated upward lightning emerging from the Tower. With the help of C-band dual-polarimetric radar data, the present work focuses on the meteorological conditions conductive to self-initiated upward lightning from the Säntis. The analysis revealed that the upward-propagating positively-charged leaders spread mostly horizontal above the melting level, after an initial short vertical path from the tower tip. After this initial stage, the majority of upward leaders were followed by a sequence of negative return strokes. The inception upward lightning under a stratiform cloud shield would be favored by the low height of the charge structure. From the obtained results, it turns out that a key feature favoring self-initiated upward lightning would be the proximity of the tower tip to the melting level.
\end{abstract}

\title{
Plain Language Summary
}

In this paper, we present a multi-sensor analysis of upward lightning emerging from the Säntis tower, in Switzerland. This telecommunications tower is a lightning "hot-spot" in Central Europe, with a hundred of lightning striking the tower every year. For this reason, the tower has been instrumented, to study the current associated to the lightning discharges that hit the tower. To complement the current measurements, a Lightning Mapping Array network was deployed around the Säntis Mountain, during the summer of 2017. This campaign allowed, for the first time in Europe, to study the three-dimensional structure of the upward leaders that initiate the process of the upward lightning from the tower. Moreover, with the help of dual-polarimetric radar data from MeteoSwiss (Switzerland Federal Office for Meteorology), the present work analyzes the meteorological conditions that favor the triggering of upward lightning from the Säntis tower.

\section{Introduction}

Understanding the mechanisms of upward lightning (UL) is an important topic in lightning research. The interest in lightning emerging from tall structures has grown in recent years, in particular due to the rapid expansion of wind energy globally (e.g. Rachidi et al., 2008; Foley et al., 2012). Recent studies have dealt with this topic, relying on comprehensive observations from high-speed video (e.g. Flache et al., 2008; Qie et al., 2011; Miki et al., 2012; Warner, 2012; Montanyà et al., 2012; Saraiva et al., 2014; Lu et al., 2012; Jiang et al., 
2014) to current measurements on instrumented towers (e.g. Diendorfer et al., 2009; Romero et al., 2012, 2013; Montanyà et al., 2014). These studies have revealed that human-built structures above a certain height are prone to initiate UL, as the tops of these tall towers emerge above the ground corona layer and are exposed to high ambient E-fields (Mazur, 2016).

However, an appreciable number of such UL may go unnoticed by conventional Lightning Location Systems (LLS), as they may contain only an initial continuous current (ICC), with neither superimposed pulses nor return strokes (Berger, 1967; Diendorfer et al., 2009; Smorgonskiy et al., 2013; Azadifar et al. 2016a). In this regard, 3D mapping systems like the Lightning Mapping Array (LMA) offer a unique opportunity to investigate upward leaders emerging from tower tips. Contrary to high-speed video, which may suffer from cloud screening effects, the LMA depicts lightning channels within the cloud with sufficient time resolution and spatial precision to locate their origin and propagation path. Relying on LMA data, Edens et al. (2012) and Hill et al. (2013), have analyzed upward-propagating leaders (UPL) on rocket-and-wire triggered lightning; Wang et al., (2018) and Schultz et al. (2018) have examined winter UL in Japan and the U.S., respectively; and Montanyà et al. (2014) and Pineda et al. (2018) have studied ULs emerging from wind turbines. These works have revealed that UL are linked to particular meteorological regimes.

Limited studies exist on the meteorological aspects favoring the inception of UL. Some focus on the windy conditions that may assist the initiation of upward leaders; since winds above a certain speed would reduce the amount of space charge accumulated in the vicinity of the tip of an object (Wang and Takagi, 2012; Becerra, 2014; Wu et al., 2017). Zhou et al. (2014) pointed out that lower ambient temperature may also have an effect on the initiation of upward leaders: keeping in mind the dependence of the electrification processes on temperature (e.g. Takahashi, 1978; Saunders et al., 2006), cloud charges are at lower altitudes in winter, favoring interaction with ground structures such as towers and wind turbines, as reported in the literature (Wang and Takagi, 2012; Schultz et al., 2018; Pineda et al., 2018). Lately, studies such as Warner et al. (2014), Jiang et al. (2014), Wang et al. (2017), Pineda et al. (2018) have incorporated weather radar data into the analysis, providing a comprehensive survey on the thunderstorm characteristics related to UL.

To shed new light on the meteorological aspects favoring the inception of upward lightning, an LMA measurement campaign was carried out during the summer of 2017 in the surroundings of the Säntis Mountain (2,505 m ASL, Switzerland), aiming to measure lightning activity at the Säntis tower (Fig.1). The campaign was a joint venture between the Electromagnetic Compatibility Laboratory (EMC-Lab) of the Swiss Federal Institute of Technology (EPFL), the University of Applied Sciences of Western Switzerland (HEIG-VD), and the Lightning Research Group (LRG) of the Technical University of Catalonia (UPC). The LMA was deployed at the end of June and was operative since mid-August. During that period, direct strikes to the Tower were registered on ten days by in-situ by EMC-Lab sensors. For the present analysis we have focused on three of them (June 29, July 10 and 14), days in which all six LMA stations were fully operative and processed data depicted upward leaders emerging from the Tower.

In particular, the present study is concerned with the cloud microphysics, electrification and charge structure favoring the inception of self-initiated upward lightning 
(SIUL) from the Säntis Tower. In this regard, the incorporation of high-resolution MeteoSwiss polarimetric radar data in the analysis provided a wealth of information concerning the thundercloud microphysical properties.

\section{Data and Methods}

During the summer of 2017, a Lightning Mapping Array system (LMA) was deployed around the Säntis Mountain aiming to measure lightning activity at the Säntis Tower (124-m tall, $47^{\circ} 14^{\prime} 57^{\prime \prime} \mathrm{N}, 9^{\circ} 20^{\prime} 32^{\prime \prime} \mathrm{E}$ ), see Figure 1 . The primary goal for data collection was to capture UL emerging from the Säntis Tower to complement the channel-base current waveforms that are currently measured at the Tower.

\subsection{Lightning Data}

\subsubsection{Lightning current measurements at Säntis}

The Säntis Tower has been instrumented by the EPFL and HEIG-VD teams to measure lightning current and its time derivative waveforms (Romero et al., 2012, 2013; Azadifar et al., 2014). Indeed, Säntis is a lightning "hotspot" in the eastern Swiss Alps, it has the highest lightning flash density in Switzerland, with about 100 flashes per year; and a relatively high value of flash multiplicity (Manoochehrnia et al., 2008). According to Azadifar et al. (2016a) lightning at the Säntis Tower is essentially of the upward type.

\subsubsection{Lightning Mapping Array}

The LMA system locates radio emissions in the very high frequency range (VHF, 60$66 \mathrm{MHz}$ ) in three dimensions by a time-of-arrival analysis of pulses using at least five stations. Each station samples the maximum signal amplitude and its GPS-derived precise time over $80 \mu$ s intervals. Typically, 2000 to 3000 sources per second are located during lightning flashes. The background noise level at the sites varies usually between $-80 \mathrm{dBm}$ and $-60 \mathrm{dBm}$. Power in dBW is available for every located source (see Rison et al. (1999), Thomas et al. (2001) and Thomas et al. (2004) for more details on LMA systems).

The deployment of an LMA in the Säntis mountainous area was challenging, since the VHF detectors require a line of sight to the Tower. The site selection was made taking into consideration practical installation aspects such as accessibility and reliable access to AC power and communication; constraints that greatly limited the number of desirable sites. Moreover, to accurately locate the three-dimensional position of a lightning source, the LMA stations must be sufficiently separated from each other so that the signal from a source arrives at each station at significantly different times (Thomas et al., 2004). In the end, some of the sensors were located within stations belonging to Swisscom and Swisscom Broadcast, which in some cases resulted in an increased noise level coming from the on-site telecommunications equipment. Despite these constrains, the background noise level was acceptable $(-75.8 \mathrm{dBm}$ to $-56.3 \mathrm{dBm})$. Due to the roughness of the terrain, the short baseline $(2-11 \mathrm{~km})$ and the different levels of background noise, the coverage of the LMA was uneven. Data processing has shown that roughly an area of 45 by $60 \mathrm{~km}$ was reliably covered 
by the network, even though the usual range of the LMA detection system is between 100200 km (Koshak et al., 2004; Fuchs et al., 2016). A minimum of five LMA stations were required to process the VHF sources, and a maximum chi-square threshold of 1.0 was set to validate source locations. Afterwards, VHF source points were grouped into flashes using the space and time criteria of Thomas et al. (2004).

\subsubsection{EUCLID lightning data}

During the campaign, the European Cooperation for Lightning Detection Network (EUCLID) provided complementary lightning data in the vicinity of the Säntis Tower. EUCLID is a consortium of 19 European national lightning detection networks with the aim of identifying and detecting lightning all over the European area (http://www.euclid.org). Details on the EUCLID system can be found in Schulz et al. (2016) and Poelman et al. (2016). EUCLID works in a frequency range different from that of the LMA and does not observe the same processes of a lightning flash. While LMA depicts the channeling process inside the cloud, EUCLID mainly provides the location of cloud-to-ground (CG) return strokes.

\subsection{Leader Speed and Charge Structure Determination}

The LMA system mainly locates sources from negative leaders propagating through positively charged regions (e.g., van der Velde and Montanyà, 2013). Weaker sources from recoil leaders (e.g., Mazur, 2002; Williams and Heckman, 2012) are detected as well, allowing the mapping of positive leaders (Shao et al., 1999; Edens et al., 2012). Interestingly, negative and positive leaders propagate at characteristic horizontal speeds $\left(10^{5}\right.$ and $2 \cdot 10^{4} \mathrm{~ms}^{-1}$ respectively); The propagation speed of the positive channels being almost an order of magnitude lower (e.g. Mazur et al., 1998; Shao and Krehbiel, 1996). Taking advantage of those characteristic speeds, van der Velde and Montanyà (2013) developed a method that allows to determine the leader speed and, therefore, to infer the leader polarity. The timedistance-altitude projection displays LMA sources by horizontal distance relative to a fixed reference point of choice, usually the flash initiation. This way, by simplifying $x-y$ into one horizontal dimension, a time axis allows a qualitative analysis of leader speed and their continuity in time and space. Reference lines $\left(2 \cdot 10^{4}, 1 \cdot 10^{5}\right.$, and $\left.1 \cdot 10^{6} \mathrm{~ms}^{-1}\right)$ for slopes of LMA sources offer guidance for the leader speed determination. Besides, using the conceptual framework of bidirectional breakdown (Kasemir, 1960; Mazur, 1989), the analysis of individual flashes helped to infer the signs and locations of the charge regions in which the leader is propagating, assuming that a lightning leader moves through charge of opposite polarity, thereby serving to neutralize space charge (Coleman et al., 2003; Rust et al., 2005; Wiens et al., 2005, Williams and Heckman, 2012; Montanyà et al., 2014).

\subsection{Weather Radar Imagery}

Polarimetric weather radar data were available from the MeteoSwiss C-band radar network (Germann et al., 2015). In particular, we made use of the Albis radar (928 m ASL, N $47^{\circ} 17^{\prime} 03.71^{\prime \prime}$, E $\left.8^{\circ} 30^{\prime} 43.31^{\prime \prime}\right)$ located near the city of Zurich, $60 \mathrm{~km}$ East from the Säntis area. Radar imagery, with a time span of $5 \mathrm{~min}$., has been used for storm morphology analysis and to estimate the horizontal dimensions of the storm system, by using the 
classifications by Parker and Johnson (2000) and Duda and Gallus (2010). Besides, a hydrometeor product (HP) has been analyzed for the SIUL events. MeteoSwiss runs operationally a semi-supervised hydrometeor classification described in detail in Besic et al. (2016). The classification is made based on five radar polarimetric variables: horizontal reflectivity $(\mathrm{Zh})$, differential reflectivity (Zdr), co-polar correlation coefficient ( $\rho$ hv) and the specific differential phase (Kdp); as well as temperature from the COSMO NWP model. The classification provides up to nine classes (see Fig. 7). The hydrometeor product can help diagnose hail cores, snow-to-rain transitions, and regions of graupel and ice particles (e.g. Dolan and Rutledge, 2009). Indeed, one of the important uses of the polarimetric weather radar data is the detection of the melting layer in stratiform precipitation, based on the conventional "bright band" signature (Kumjian, 2013). The bright band (BB) is a thin, rather horizontal layer of enhanced radar reflectivity resulting primarily from the fast increase in the dielectric constant of particles during the melting process (e.g. Austin and Bemis, 1950; White et al., 2002). The layer over which the transformation from ice to water occurs defines the melting layer. The top of the melting layer is the melting level, also commonly accepted as the altitude of the $0^{\circ} \mathrm{C}$ constant-temperature surface.

\subsection{Ancillary data}

Vertical temperature profiles for the Säntis area were obtained by means of modeloutput soundings from MeteoSwiss. Key environmental temperatures $\left(0^{\circ} \mathrm{C},-10^{\circ} \mathrm{C},-20^{\circ} \mathrm{C}\right.$ and $-40^{\circ} \mathrm{C}$ ) related to the convective microphysical and electrification processes (e.g. Krehbiel, 1986; Brook et al., 1982; MacGorman and Rust, 1998) were selected from these profiles.

Besides, visible and infrared imagery from the Meteosat satellite were used to monitor cloud systems that affected the area of study. Cloud top temperatures from the infrared channel were used for cloud system characterization (Maddox, 1980; Maddox et al., 1983). The morphological scheme proposed by Jirak et al. (2003) was used to characterize Mesoscale Convective Systems (MCS).

Finally, wind direction and speed data, measured by a MeteoSwiss weather station, was gathered for the analyzed episodes. The Säntis meteorological station is located on top of the Säntis Mountain near the instrumented tower.

\subsection{Self-initiated vs. lightning triggered upward lightning}

ULs can be classified into two basic types (e.g. Wang and Takagi, 2012), either selfinitiated (SIUL) due to locally strong electric fields; or lightning-triggered (LTUL) when induced by prior lightning discharges in the vicinity, which provide the necessary electric fields for the inception and stable propagation of an upward leader. The proportion of SIUL and LTUL reported in the literature shows substantial differences from tower to tower (see Smorgonskiy et al., 2015 and references therein). Smorgonskiy et al. (2015) pointed out that the underlying causes of such differences are diverse whether physical (tower effective height, topographical conditions, other tall structures in the vicinity) or methodological (e.g. time window and distance to the tower to determine prior CG lightning in the vicinity). In this regard, intra-cloud channels propagating overhead may also induce LTUL, and its consideration (or not) in the method to report prior lightning activity in the vicinity of the tower may have a great influence on the SIUL/LTUL proportion obtained. In the present study, UL 
from the Säntis were classified as LTUL or SIUL depending on whether or not lightning activity (either from LMA or EUCLID) had been reported within a distance of $30 \mathrm{~km}$ around the tower and within a 5-s time window before the start of the flash.

\section{Results}

3.1. Self-initiated upward lightning from Säntis

A clear depiction of SIUL at the Säntis Tower was obtained through the combination of LMA, current waveforms measured at the Tower and lightning detections by EUCLID. Figure 2 shows an example. The initial continuous current (ICC) measured at the Tower, associated with the upward-propagating positively-charged leader (+UPL) phase, lasted for about $400 \mathrm{~ms}$ and effectively transported negative charge to ground. The UPL, together with the ICC, comprise the initial stage (IS) of the UL. After the IS, a sequence of twelve returnstrokes carried additional negative charge to ground (Figure 2a), similar to those in downward negative lightning discharges (Rakov and Uman, 2003). Eight of these strokes at the Tower were detected by EUCLID. Note that the measured peak values are lower than Euclid-estimated values. The overestimation of EUCLID (by a factor of 1.7 approx.) is due essentially to the presence of the mountain as discussed in Azadifar et al. (2016) and Li et al. (2016). Focusing on the ICC phase, Figure $2 b$ shows the LMA VHF sources associated with the development of the +UPL, some of them concurrent with the impulsive current pulses occurring in this stage of discharge.

Nineteen self-initiated upward leaders emerging from the Säntis Tower, like the one presented in Figure 2, were recorded on three different days during the campaign. A summary is given on Table 1. The majority of these UPL were mapped by the LMA with sufficient resolution of leader channels to clearly identify characteristics such as the channel origin, maximum altitude and polarity. Detailed analysis of the current measurements at the Tower related to these events will be the subject of a future paper.

Multiple current pulses and corresponding EUCLID-detected strokes (either IC or CG) were measured in sixteen of the nineteen events. As many as 51 pulses and 47 strokes were associated with a single LMA flash (event \#8). Statistical distributions from Romero et al. (2013) show that the flash multiplicity at Säntis has a lognormal distribution with a median of 8 pulses per flash, with a maximum of 69 . The UL analyzed in the present study had a larger mean multiplicity, with 19. Schultz et al. (2018) also reported multiple CG flashes associated with LMA observations of UL during electrified snowfall events (data from the U.S. National Detection Lightning Network, NDLN).

Almost all EUCLID strokes at Säntis associated with SIUL were of negative polarity, only event \#18 presented a $4.5 \mathrm{kA}$ positive stroke (bipolar flash). The largest magnitude negative CG stroke showed a peak current of -55.6 kA (event \#15), and the population's average and median peak currents were $-16.7 \mathrm{kA}$ and $-15.8 \mathrm{kA}$, respectively (for those classified as CG by EUCLID). Romero et al (2013) reported a peak current average of -6.4 $\mathrm{kA}$. 
At this point, it may be noticed that EUCLID data are being presented as is, keeping in mind that some events can be misclassified. That is to say, ICs may be CGs, and vice versa (Cummins and Murphy, 2009). In fact, Warner et al. (2014) noticed that NLDN detections (same detection technology as EUCLID) following the development of UPL from towers had a higher rate of misidentification. According to Azadifar et al. (2016b), who also reported a higher rate of misidentification of EUCLID data for the Säntis, this can be explained by the fact that ICC pulses with short current rise times are associated with leader/return stroke mode discharges to an existing channel branch at some height above the tower tip. Another reason for misclassification is related to the electric fields radiated from return strokes on tall towers, which might have a shorter peak-to-zero time (Pichler et al., 2010).

The time interval between the initiation of UL (first detected LMA source) and the first stroke measured at the Säntis tower (pulses above 2kA) was between 25 and $701 \mathrm{~ms}$, with an average of $202 \mathrm{~ms}$. Taking as a reference the first CG stroke according to EUCLID, delays were between 122 and $853 \mathrm{~ms}$, with an average of $318 \mathrm{~ms}$. Similarly, Schultz et al. (2018) reported a time span of about $200 \mathrm{~ms}$ (up to $600 \mathrm{~ms}$ ) between the upward progression of the first VHF source points from the LMA and the first NLDN detection at the tower location.

\subsection{Leader speed and polarity}

The leader polarity of the UL from Säntis has been inferred by using the time-distance graph (van der Velde and Montanyà, 2013), which allows to separate simultaneous positive and negative leaders by altitude and apparent speed of propagation. As an example, Figure 3a shows the upward leader of event \#9 in a time-distance representation, with the leader origin (first detection) as $\mathrm{t}=0$. Dashed lines provide a reference for slopes of leader traces corresponding to different 2-D radial speeds relative to the origin. The leader is progressively moving away from the origin, at a rather constant height (source color) yielding a slope corresponding to an average radial speed around the $2 \cdot 10^{4} \mathrm{~ms}^{-1}$ reference line, typical of positive leaders. Figure $3 \mathrm{~b}$ shows another example, this time event \#11. The first upward leader follows the slope corresponding to a positive leader. Interestingly, this event presented, $300 \mathrm{~ms}$ after the +UPL inception, another leader that moved upwards to spread horizontally at about $\sim 6 \mathrm{~km}$, this time with an average speed close to the negative reference $\left(10^{5} \mathrm{~ms}^{-1}\right)$. VHF source power recorded by the LMA from this upward-negative leader averaged 16 $\mathrm{dBW}$, whereas preceding sources from the initial positive leader averaged $6.5 \mathrm{dBW}$ Columns 4 and 8 on Table 1 show the number of sources per UL and the leader polarity according to the leader speed determined with this method. In cases with few LMA sources, where the leader speed cannot be properly assessed, leader polarity has been labeled as "unknown". 


\subsection{Case study overview}

\subsubsection{June 29 th}

On this day, the sequence of Meteosat imagery showed convective cells developing in central and southern Switzerland around 12:00 UT, which moved northeastward across the Säntis region during the afternoon. With time, the group of cells ended organized as an MCS (Jirak et al., 2003). Corrected reflectivity from the Albis radar showed a nonlinear convective system (Duda and Gallus, 2010) approaching from the SW and crossing the Säntis region from SW to NE. From 13:20 to 13:50 UT, the convective cores of the MCS crossed the Säntis tower. Lightning flash rates (hereafter LFR) derived from LMA and EUCLID showed maximum values of 29 IC flash $\min ^{-1}$ (14:00-14:10 UT) and 4-5 strokes $\min ^{-1}$ (14:00-14:10 UT) respectively. At the time of crossing above the Tower, the large majority of the flashes detected by the LMA in the main convective core concentrated in areas where rimed particles and solid hail were dominant.

According to the LMA measurements, up to fourteen UPL were triggered by the Tower during this episode, those having enough sources were all classified as +UPL. For eleven of them, the current waveforms were measured at the Tower and the strokes detected by EUCLID (either IC or CG). The first upward leader emerging from the Säntis tower tip mapped by the LMA was at 14:02:00 UT (event \#1 in Table 1). It appears to be an upward leader with no fast pulses since it was not measured at the Tower, neither by EUCLID. Note that the triggering system at Säntis Tower is based on the current derivative. The system will not trigger in the case of absence of any fast pulse. According to the studies in Gaisberg [Schulz et al., 2016], upward leaders not followed by fast pulses could represent as much as $40 \%$ of upward flashes. Contrarily, the two following +UPL occurring minutes after (events \#2 at 14:06:12 UT and \#3 at 14:08:39 UT), ended in a sequence of negative pulses recorded at the Tower and also reported by EUCLID (-CG). Figure 4 displays a basemap of corrected reflectivity (4 km height ASL) at 14:05-14:10 UT. The overlayed LMA VHF sources show to clusters of activity. The first one corresponding to a convective core embedded in the rainfall system, $25 \mathrm{~km}$ away from the Tower; the second group of VHF sources are UPL spreading away from the Tower (events \#2, 14:06 UT and \#3, 14:08 UT).

The upward propagation of these three leaders is depicted by the vertical trail of first VHF sources emanating from the tower location (Figure 5), changing to mostly horizontal upon reaching the $4 \mathrm{~km}$ altitude, just below the $-10^{\circ} \mathrm{C}$ isotherm, according to the vertical temperature profiles. The velocity of these horizontally propagating channels, as inferred from the time-distance projection, was similar to the reference for positive leaders $\left(2 \cdot 10^{4} \mathrm{~ms}\right.$ ${ }^{1}$ ). Assuming these leaders propagated through charge of opposite polarity, these +UPL connected therefore with a negative charge layer in the cloud, and later resulted in negative pulses to the tower (except for the aborted leader in \#1). 
After another +UPL at 14:11:09 UT with up to 30 pulses detected by the Tower and 25 strokes according to EUCLID (event \#4), activity at the Tower paused for almost an hour. In the meanwhile, the convective cores moved away and the radar sequence showed an extensive rainfall field with moderate reflectivity. Two other UPL were detected by the LMA at 15:05:42 UT (\#5) and 15:10:52 UT (\#6). The tower recorded 20 negative pulses (EUCLID 22) associated to event \#5 and 3 negative pulses (EUCLID 4) for event \#6. Later on, two other tower-initiated +UPL were detected by the LMA (event \#7 at 15:36:50 UT and \#8 at 15:39:46 UT). As shown in Figure 6a, the only lightning activity in the vicinity of the Tower during the radar time span (15:35-15:40 UT) was these ULs from the Tower, spreading to the rear edge of the storm under an extensive stratiform rainfall field of moderate reflectivity.

Radar vertical cross sections (XSEC) of the ALBIS radar were used to characterize the vertical structure of the storm during the upward lightning events. Figure $6 \mathrm{~b}$ shows the XSEC on the reflectivity volume (XSEC-R) at 15:35-15:40 UT, encompassing events \#7 (15:36:50 UT) and \#8 (15:39:46 UT). The Säntis tower tip was close to the $0^{\circ} \mathrm{C}$ isotherm, near the melting level (top of the melting layer). As frozen particles fall through the melting level, the meltwater on their surfaces promotes higher radar reflectivity (i.e. bright band) readily recognized by the horizontal layer of enhanced radar reflectivity (35 to $40 \mathrm{dBZ}$ ). A progressive decrease in reflectivity with increasing height above the BB can be observed in the XSEC-R, a typical pattern in MCS stratiform regions (Steiner et al., 1995; Biggerstaff and Listemaa, 2000).

Likewise, the cross section on the hydrometeor classification product (XSEC-H) at 15:35-15:40 UT (Figure 7a) shows a vertical sequence of stratified layers, from rain in the bottom to ice crystals at the top. Notice that the HP itself is already a phase and temperature indicator: rain categories indicate positive temperatures; wet snow and melting hail correspond to temperatures near $0^{\circ} \mathrm{C}$ and all the ice-phase hydrometeor types indicate negative temperatures. The BB is classified as wet snow (WS) in the HP (Grazioli et al., 2015; Besic et al., 2016). On top of the WS, a layer of rimed ice particles (RP) is observed. Above, the $-10^{\circ} \mathrm{C}$ isotherm marks the transition to aggregates (AG). AG are made up of a conglomeration of ice crystals with diameters ranging from 1 to $12 \mathrm{~mm}$ (Locatelli and Hobbs, 1974). The aggregation maximum is around $-10^{\circ}$ to $-15^{\circ} \mathrm{C}$, associated with the dendritic ice habit growth regime (Hobbs et al. 1974; Field, 1999). Finally, the higher layers (around the $20^{\circ} \mathrm{C}$ isotherm) appear composed by a mixture of two categories, ice crystals and vertically aligned ice (VI). Ice crystals (CR), sometimes being vertically aligned (VI) are observed at the cloud top, and are dominant below $-15^{\circ} \mathrm{C}$ (Field, 1999). The +UPL of events \#7 and \#8 overlayed to the XSEC-H reached the transition between the RP and the AG ( $\sim 5 \mathrm{~km}$ height) (Figure 7a).

Events \#9 (15:45:52 UT) and \#10 (15:47:31 UT) had a pattern similar to prior ULs, with a short vertical trail of VHF source points emanating from the tower location and, spreading quasi- horizontally near four km height (within the RP category layer). Figure 3a showed that horizontal propagating channel on event \#9 had a speed similar to the positive reference. Interestingly, event \#11, which occurred shortly after 15:50:02 UT, is seemingly more complex (Figure 7b). It started as the previous events, with a +UPL. However, after 400 
ms (and a CG stroke of $-6.6 \mathrm{kA}$ ), a very well resolved negative leader (Figure 3b) rapidly accelerated upwards to spread horizontally at about $\sim 6 \mathrm{~km}$, reaching the transition between $\mathrm{AG}$ and the layer of ice crystal mixture and revealing the existence of a positive charge region above. Upward bi-level intracloud discharges have been already reported by LMA systems, during winter storms (e.g. Shi et al., 2018) and on rocket-triggered lightning (e.g. Hill et al., 2013). Finally, the activity at the tower ended with three events 15:54:55 UT (\#12), 16:00:13 UT (\#13) and 16:05:36 UT (\#14), all with a similar pattern to events \#9 and $\# 10$.

All in all, fourteen SIUL from the Säntis Tower were recorded during this episode over a time span of two hours. All of them started with a UPL, spreading horizontal between 4 and $5 \mathrm{~km}$ (temperatures between $-5^{\circ} \mathrm{C}$ and $-10^{\circ} \mathrm{C}$ ). Events from 15:36 UT to 15:54 UT (\#7 to \#12) showed longer channels, spreading and branching out toward the west, in opposite direction to the cloud system motion. The Säntis Tower system measured a total of 251 strokes (pulses > 2kA) associated with these 14 SIUL, ranging from 3 to 51 per event, with an average of 21 strokes per flash. The EUCLID network detected up to 248 of these strokes.

\subsubsection{July 10 th}

On this day, the sequence of Meteosat imagery showed convective cells developing in central France around 12 UT. Like the June 29 episode, the multicellular system grew to become a MCS before reaching the Säntis region around 18:30 UT. The most active core of the system crossed Switzerland to enter south Germany by 20:30 UT, to the north of the Säntis region. By 20:15 UT, the MCS had reached its maximum extension, with an area of more than $90,000 \mathrm{~km}^{2}$ (cloud shield with continuously cloud tops below $-52^{\circ} \mathrm{C}$, Jirak et al. (2003)).

With a higher spatial resolution, the radar observations showed the first convective cores appearing west of the tower, in the area of the LMA, around 18:00 UT. The radar reflectivity imagery displayed small convective cores crossing the Säntis region from SW to NE, embedded into a stratiform rain field. Those small cores were irregularly distributed; appearing here and there and showing a short life-cycle sequence of developing-maturitydecaying (30-45 min) all passing to the north of the tower. According to the Duda and Gallus (2010) scheme, the system can be defined as a nonlinear convective system. Around 19:45 UT, a more organized multi-cell system appeared west of the tower, in the area of the LMA, and traversed above the tower west to east. At 20:30 UT, an active cell passed above the tower. LMA and EUCLID reported the maximum lightning activity between 20:10 UT and 20:30 UT, with a maximum LFR of $50 \mathrm{IC}$ flash $\mathrm{min}^{-1}$ and 5 strokes $\mathrm{min}^{-1}$ respectively. At that time, the altitude histogram of the number of LMA sources showed a bimodal distribution, with a maximum around $4 \mathrm{~km}\left(-5^{\circ} \mathrm{C}\right)$ and a secondary maximum around $6,5 \mathrm{~km}\left(-20^{\circ} \mathrm{C}\right)$, indicative of a classical tripole charge structure (Williams, 1989) with a dominant lower positive charge region (Nag and Rakov, 2009).

Over time, the system progressively organized and, around 21:00 UT, a line of convection was finally apparent in the radar base map to the East of the tower. Then, during approximately an hour, the tower remained under the stratiform cloud system that followed. 
Three UL events were recorded during this episode (events \#15, \#16 and \#17 in Table 1). They all occurred in a period of $30 \mathrm{~min}$ approx., between 20:48 UT and 21:19 UT. The decreasing LFR indicates that at that time convection was decaying in the LMA area of coverage, with the lightning activity mostly limited to the Tower. Only a few IC were detected by the LMA, but far from the Tower, apparently having no triggering effects on the three ULs. Event \#15 (20:48:57) was poorly mapped by the LMA and only a few sources were detected above the tower tip.

Ninety-three milliseconds after the first LMA source, the Tower recorded the first of 14 pulses (13 strokes in EUCLID). All had negative peak current, with a maximum value of $23 \mathrm{kA}$ (-55 kA in EUCLID). Event \#16 was better mapped by the LMA and the time-distance graph indicated a +UPL (not shown). There were 10 pulses at the tower for this event (all detected by EUCLID), with a similar delay (104 ms). The best LMA-resolved +UPL emerging from the Säntis during this episode was event \#17 (21:19:37 UT). In this case, the five pulses at the Tower (also detected by EUCLID) had lower peak currents (max. $-8.7 \mathrm{kA}$ ) and longer delay (353 ms).

Similar to the June 29 episode, the basemap of corrected reflectivity at the time of the ULs showed an extensive field of moderate reflectivity (25-35 dBZ), corresponding to the trailing stratiform part of an MCS. The XSEC-R related to event \#17, displayed in Figure 8 (a), along with the vertical temperature profile, showed the bright band around $3 \mathrm{~km}$ height. Reflectivity values decreased with height, with the lowest values reaching 6-7 km ASL, indicative of a moderate cloud vertical development. The overlay of the +UPL corresponding to event \#17 shows how the horizontal path of the channel was just above the melting level, a pattern observed in other UL studies (e.g. Hill et al., 2013; MacGorman et al., 2014).

The BB can also be inferred from the horizontal layer of WS in the XSEC-H (Figure $8 b$ ). In contrast to the June 29 case, the vertical stratification on July 10 was less clear (and the bright band is not so clear cut). Below the melting level, there was a mixture of rain $(\mathrm{RN})$ and light rain (LR). Above, HP showed AG with some patches of RP. The patchy pattern may be a consequence of previous turbulences. Finally, at higher levels, above the $-20^{\circ} \mathrm{C}$ isotherm, the product identified traces of CR and VI.

\subsubsection{July 14 th}

On this day, convective cores crossed the Säntis area from NW to SE. The convective system that induced ULs from the Tower can be characterized as a cluster of cells (Duda and Gallus, 2010). The two ULs recorded at the Tower were isolated events, separated by more than half an hour. LFR over the region of LMA coverage was lower than in the preceding events, with two periods of moderate activity, showing maxima around 13:10 UT and 15:20 UT with a LFR of 5 IC $\mathrm{min}^{-1}$ and 1 stroke $\mathrm{min}^{-1}$, according to LMA and EUCLID respectively. While other IC occurred in convective cores in the vicinity of the Tower, the two ULs at the Tower (events \#18 and \#19), were isolated SIUL.

Event \#18 was not very well resolved by the LMA; the 20 VHF sources show a quasivertical leader reaching $5 \mathrm{~km}$ height. According to the measurements at the Tower, event \#18 was an upward bipolar flash. A first positive pulse occurred at about $265 \mathrm{~ms}$ after the start of the +UPL. A negative pulse was recorded shortly after, two negatives followed later on. All these strokes, including the positive, were recorded by EUCLID. 
Contrarily, event \#19 was very well resolved by LMA, although there were no current measurements at the Tower, nor EUCLID detections. In spite of what looks like a branched UPL, in this case the lack of current measurements at the tower cannot confirm it has emerged from the Tower. The basemap of corrected reflectivity (Figure 9a) shows a leader heading west of the Tower, branching once before the end. Besides, there were two other small branches at the beginning, that could have also been leaders starting at the Tower.

In contrast with the June 29 and July 10 events, the SIUL took place under small cloud structures with a cloud shield around $500 \mathrm{~km}^{2}$. Besides, although SIUL occurred with moderate reflectivity, this time convective cores were present shortly after or nearby the Tower (Figure 9a). The XSEC-R related to events \#18 and \#19 showed moderate vertical development (6-7 km ASL). Vertical temperature profiles situate the $0^{\circ} \mathrm{C}$ isotherm at $2700 \mathrm{~m}$ ASL, whereas the XSEC-H allows to estimate the melting level, at around $3 \mathrm{~km} \mathrm{ASL}$ (wet snow layer in Figure 9b). The overlay of event \#19 shows the positive leader developing horizontally just above the melting level. Above, there was mostly AG at the time of the upward leader's inception. Unlike previous episodes, RP were residual, and VI was found at lower levels, even below the $-10^{\circ} \mathrm{C}$ level.

\section{Discussion}

\subsection{Upward positive leaders}

Studies on towers around the globe have reported a majority of ULs initiated by +UPL (e.g. Wang et al., 2008; Zhou et al., 2012; Yuan et al., 2017). As an example, only 4\% of the flashes at the Gaisberg tower in Austria are initiated from the tower by a negative leader (Zhou et al., 2012). This proportion is around 12\% at Säntis (Azadifar et al., 2016a). In the present study, current measurements at the tower provide strong evidence on the positive polarity of all reported upward leaders initiating UL from the Säntis (example in Fig.2). Positive polarity is also supported by the negative polarity of the lightning pulses detected by EUCLID (Table 1); as well as by the leader speed determined by the van der Velde and Montanyà (2013) method, showing speeds around the $2 \cdot 10^{4} \mathrm{~ms}^{-1}$ reference, typical of positive leaders (e.g. Proctor et al., 1988; Mazur et al., 1998; Shao and Krehbiel, 1996).

An important question is whether positive breakdown itself produces locatable VHF emissions in +UPL, or if the VHF sources associated with positive leaders actually originate from retrograde negative breakdown (recoil leaders), which may occur close to the tips of positive leaders and be short in extent (Mazur, 2002; Williams and Heckman, 2012). Eventually, the relatively weak positive VHF sources can be recorded when average current is higher than $3 \mathrm{kA}$ and has significant pulse activity (Yoshida et al., 2010). Besides, Edens et al. (2012) suggested that positive breakdown does produce low power VHF emissions, but are only detectable with TOA techniques when no concurrent negative breakdown occurs that produces strong VHF emissions, which is the case for isolated +UPL. Observations of +UPL have been achieved by a small-baseline LMA configurations, like in Hill et al. (2012), Edens et al. (2012) or MacGorman et al (2014). Similarly, the LMA deployed around the Säntis nicely depicted UPL emerging from the Säntis Tower.

In the present study, branching was observed in 16 of the 19 events recorded. For the other three (events \#6, \#14, \#15), the paucity of sources did not allow to assess any 
branching. Although the recorded VHF sources were not sufficient to reconstruct the branching on each UPL into detail, they were good enough to estimate the height at which the first branching occurred. As Hill et al. (2012) pointed out, as branching generates more channels, many of which are propagating simultaneously, its mapping losses accuracy due to the time resolution of the LMA ( $80 \mu$ s per source location). Over time, the UPL typically appear as broad regions of more diffuse source locations. Nonetheless, branching started once the initial vertically-propagating continuous channels turned abruptly horizontal. It seems that the branching of the leader may be related to the similar potential differences between the leader tip and its environments at different directions. Before reaching the charge layer, the upward direction evolves the largest potential difference (in Z). While in the charge layer, multiple horizontal directions (in X, Y) may evolve comparable potential difference, giving rise to the branching of channel or splitting of leader tip.

\subsection{Storm morphology and charge structure}

On the days of study, the peaks of activity detected by the LMA were associated to convective cores, embedded on larger thunderstorm systems that crossed above the Säntis tower. The three-dimensional picture of the charge structure on these cores corresponds to the classical tripole charge structure (Williams, 1989), with a main negative layer of roughly 5-6 $\mathrm{km}$ height corresponding to temperatures of $-10^{\circ} \mathrm{C}$ and $-15^{\circ} \mathrm{C}$, respectively, a lower positive charge center $\left(3.5-5 \mathrm{~km}, 0^{\circ} \mathrm{C}\right.$ to $\left.-5^{\circ} \mathrm{C}\right)$ and an upper positive $\left(6-7.5 \mathrm{~km},-15^{\circ} \mathrm{C}\right.$ to $\left.-25^{\circ} \mathrm{C}\right)$. The large majority of lightning initiated in areas with radar reflectivity above $40 \mathrm{dBZ}$, where rimed particles and solid hail are dominant (Figueras i Ventura et al., 2019). Maximum flash rates on the cloud-to-ground activity, dominated by negative CGs, were also linked to these cores. However, no pulses were detected at the Tower on these periods of maximum activity.

Contrarily, SIUL at Säntis occurred under the stratiform precipitation region of these systems, once the convective region had passed away from the tower. Yuan et al (2017) reported similar conditions for SIUL inception at the Beijing Meteorology Tower. Indeed, UL are usually observed under the stratiform region of MCSs (e.g. Warner et al., 2014; Schulz et al., 2018). Unlike the convective core area, the stratiform region may have many stratified charge regions, which can persist for hours and are thought to be created by a mixture of the in-situ and advective charge processes (e.g. Stolzenburg et al., 1994; Dye and Willett, 2007; Schuur and Rutledge, 2000a, 2000b).

In spite of the scarce activity during the statiform phase, almost limited to SIUL originated at Säntis, some aspects of the cloud charge structure can be inferred from the altitude distribution of LMA source locations. The display of a preferred path for propagation is indicative of either high-electric fields (e.g., Coleman et al., 2003, 2008) or concentrated charge (Williams et al. 1985, Mansell et al. 2002) related to the presence of characteristic hydrometeors in that range (Hill et al 2013). Balloon-borne electric measurements carried on stratiform regions (Stolzenburg and Marshall, 2008 and references therein) typically found a sharpest charge transition associate to the melting level, the change in dielectric constant enacted when ice phase hydrometeors melt to become raindrops. However, what is less clear, as pointed out by Hill et al (2013), is whether the radar structure, like the melting level, simply delineates charge regions or, like the descending precipitation packets, may actively 
contribute to local enhancements in electric fields or lowering of the breakdown field favoring the propagation of the upward leaders.

In the present case study, UPL mapped by LMA feature short vertical paths, after which they change to mostly horizontal upon reaching the top of the melting level, where according to the radar profiles, hydrometeors switched from frozen particles (rimmed particles, aggregates) to water-coated particles (melting hail, wet snow). Based on the positive polarity of the UL triggered by the Säntis Tower, we assume that those channels propagated through negative charged regions, just above the melting level. Moreover, one of the last UL observed on June 29 (event \#11) presented, after the initial +UPL, a negative leader (Figure $3 b$ ) that reached the $-20^{\circ} \mathrm{C}$ level, where XSEC-H showed a transition from AG to a mixture of VI and CR (Figure 7b). The recording of this upper negative leader by the LMA revealed the existence of a positive charge region above. The radar cross section shows a general correspondence between the electrical structure drawn by the UL channels and the stratified HP categories. This microphysical structure is in agreement with the conceptual model presented by Schuur and Rutledge (2000 a,b), where charge transitions coincide with peak aggregation layers: particle separation due to fallspeed differences causes the charge transitions immediately above the melting level $\left(\sim 1^{\circ} \mathrm{C}\right)$, and also near the $-12^{\circ} \mathrm{C}$ isotherm. In our case, these key temperatures are related to the transitions between WS and RP and RP and $A G$ respectively.

On the basis of the layered nature of the hydrometeor categories, and assuming the charge structure could be similarly layered across the stratiform region, the occasional measurements of height and polarity obtained from the UL by the LMA can help determining the polarity of such layers. Based on this hypothesis, the layer of rimed particles between $0^{\circ} \mathrm{C}$ and $-10^{\circ} \mathrm{C}$ corresponds to the main negative layer, with a low-density positive above (aggregates and ice crystals between $-10^{\circ} \mathrm{C}$ and $-20^{\circ} \mathrm{C}$ ). Taking into account the charge transition associated to the melting level, the melting layer would be positively charged. The resulting structure could fit with the conceptual model proposed by Stolenzburg et al. (1994) for the trailing stratiform regions of MCSs. However, in the absence of balloon-borne electric field measurements, the few and small negative charge regions revealed by the +UPL above the melting level could also correspond to charge pockets of charge associated to pockets of rimed particles or aggregates. According to Barnes and Houze (2014) such pockets can occur intermittently with small-scale spatial variability just above the melting layer, as a result of collapsing deep convective cores (Houze 1997) or small, localized convection embedded within the mesoscale stratiform updraft that is associated with internal instability (Houze and Medina, 2005).

Finally, the layered charge structure cloud also match with the one presented in Marshall et al. (2009) corresponding to the dissipation stage of the storms and linked to the end-of-storm oscillation (EOSO) pattern. The EOSO consists of several polarity changes over a period of 30-75 min in the electric field at the ground beneath decaying thunderstorms (e.g., Moore and Vonnegut, 1977; Marshall and Lin, 1992; Williams et al., 1994; Pawar and Kamra, 2007). The conceptual scenario for the EOSO by Marshall et al. (2009) shows a progressive descent of the charge regions, which bring them closer together. In turn, this would cause an approximation of the main negative charge layer to the surface, favoring the 
+UPL inception. Unfortunately, in the present study there were no measurements on the electric field at the ground allowing to observe the EOSO pattern.

\subsection{Temperature}

The occurrence of UL from tall structures has been related to the height of $-10^{\circ} \mathrm{C}$ temperature level, where the main negative charge center frequently resides regardless of the season (e.g. Saito et al 2009, Shindo et al. 2015). Upward lightning tends to occur when the $-10^{\circ} \mathrm{C}$ altitude is below $5.500 \mathrm{~m}-6.000 \mathrm{~m}$ asl at the Tokyo Skytree (Shindo et al., 2015). Similar observations have been reported in other instrumented towers like Peissenberg, Germany (Heidler et al., 2013), Gaisberg, Austria (Zhou et al 2014) Morro do Cachimbo, Brazil (Araujo et al. 2012), Tosa d'Alp, Spain (Pineda et al., 2018) and also at Säntis (Azadifar et al., 2016c). Temperature has also a bearing on the proportion between SIUL and LTUL. Mostajabi et al (2018) have reported a mean value of surface air temperature of -0.2 ${ }^{\circ} \mathrm{C}$ for SIUL at Säntis, compared to $8.2^{\circ} \mathrm{C}$ for LTUL. Similar results were reported by Zhou et al 2014 for Gaisberg. Considering the effective height of these towers, the $-10^{\circ} \mathrm{C}$ altitude below $5.500 \mathrm{~m}-6.000 \mathrm{~m}$ asl means a short distance between the main charge layer and the tip of the tower, enhancing the electric field, setting conditions for the inception of upward lightning.

In the present case study, at the time of SIUL, the $-10^{\circ} \mathrm{C}$ altitude was between 4.500 $\mathrm{m}$ and $5.500 \mathrm{~m}$ asl. Besides, radar cross sections showed that the tip of the Säntis tower was close to the melting level. This would place the inception point beyond the maximum potential associated with the dense charge layer associated to the melting layer, exposing the tip of the tower to a negative charge layer (or pocket).

If the opposite is the case, where the tower would have been exposed to a main positive charge layer instead, the upward leaders emerging from the tower should have been of negative polarity. In fact, the inception of negative UL is more difficult, as they require electric fields more intense than positive streamers, by a factor of about two about factor of two (Bazelyan and Raizer, 2000). This could be the main reason why studies on towers around the globe have reported a majority of ULs initiated by +UPL.

\subsection{The role of wind in SIUL triggering}

At last but not least, the wind may play a role in the SIUL inception. A strong wind, not uncommon at the top of very tall structures, can remove the corona shield, thus clearing the way for initiation of an upward leader. According to Mazur (2016) this is the most probable explanation for the upward leader inception in the absence of preceding nearby lightning flashes. For example, Wang and Takagi (2012) noted that self-initiation occurred with higher observed wind speeds (or a rotating windmill) compared with LTUL. Warner et al. (2014) suggested, during blizzard conditions in the US, that notable winds may have played a key role in SIUL, by "stripping" away much of the corona discharge shielding grounded tall structures.

Mostajabi et al. (2018) have analyzed, on a longer dataset of UL at Säntis, the influence of the wind speed on the initiation of SIUL and LTUL. Results showed an increasing percentage of SIUL as a function of the wind speed. For wind speeds of $12 \mathrm{~ms}^{-1}$ and higher, 30 of the upward flashes were SIUL, out of a total of 31. Moreover, beyond 17 
$\mathrm{ms}^{-1}$ only SIUL flashes were observed. Regarding the SIUL in the present study, wind measurements from the MeteoSwiss weather station at Säntis, were available (Table 1). Even though wind data did not cover all events, measurements at the beginning of each of the three sequences of SIUL were available. Conditions were similar to those reported by Mostajabi et al. (2018), suggesting that wind speed has a bearing on SIUL inception.

\section{Conclusions}

In this paper we have presented an analysis of comprehensive observations of selfinitiated upward lightning emerging from the Säntis tower, a lightning hotspot in Central Europe. Data from an LMA network, deployed around the Säntis Mountain during the summer of 2017, along with polarimetric weather radar measurements, allowed to infer the charge structure conductive to the self-inception of UL from the tower. Common features on the observed SIUL are summarized on the following:

- Upward-propagating positively-charged leaders (+UPL) mapped by LMA showed a short vertical path, changing to mostly horizontal around $4 \mathrm{~km}$ height ASL. Branching was observed in most of the +UPL, after they turned abruptly horizontal. The time interval between the initiation of UL and the first stroke measured at the Säntis tower was between 25 and $701 \mathrm{~ms}$ with an average of $202 \mathrm{~ms}$. Almost all EUCLID strokes associated with SIUL were of negative polarity, only one SIUL event was a bipolar flash. CG strokes average and median peak currents were $-16.7 \mathrm{kA}$ and $-15.8 \mathrm{kA}$, with a maximum peak current of $-55.6 \mathrm{kA}$

- Polarimetric radar measurements on the cloud shield showed a layered structure, continuous across the stratiform region (at least in the vicinity of the tower). The "bright band" signature allowed to clearly locate the melting layer (3-4 km height ASL).

- Collocated LMA and radar cross sections showed a preferred path for the UPL horizontal propagation, just above the melting level.

The layered nature of the radar-derived hydrometeor categories, along with the horizontal paths of the UPL mapped by the LMA, suggests that the charge structure is similarly layered. However, the scarce LMA activity during the statiform phase, almost limited to SIUL originated at Säntis, is not sufficient to draw a clear picture of the overall charge structure. The occurrence of UL from tall structures has been related to the low height of $-10^{\circ} \mathrm{C}$ temperature level, conditions that are fulfilled in the present study. Indeed, a short distance between the main charge layer and the tip of the tower enhances the electric field, favoring the inception of upward lightning from tall towers. In this regard, from the current analysis it follows that a key feature favoring self-initiated upward lightning would be the proximity of the tip of the tower to the melting level.

\section{Acknowledgments}

The Säntis LMA campaign was a joint venture between the Electromagnetic Compatibility Laboratory (EMC Lab) of the Swiss Federal Institute of Technology (EPFL), based in Lausanne (Switzerland), the University of Applied Sciences of Western Switzerland (HEIG-VD), based in Yverdon, Switzerland, and the Lightning Research Group (LRG) of the 
Technical University of Catalonia, based in Terrassa, Barcelona (Spain). The Nowcasting Division of the Federal Office of Meteorology and Climatology of MeteoSwiss provided data from the MeteoSwiss C-band radar network. The original lightning mapping array (LMA) data and related files of this study have been deposited in a permanent scientific data repository: https://doi.org/10.5281/zenodo.3467102.

This work was supported in part by the Swiss National Science Foundation (Project No. 200020_175594), the European Union's Horizon 2020 research and innovation program under grant agreement No 737033-LLR, and the Spanish Ministry of Economy and the European Regional Development Fund (FEDER) ESP2015-69909-C5-5-R and ESP201786263-C4-2-R

\section{References}

Araujo LS, M.B. Guimaraes, A.G. Pedrosa, M.H. Murta Vale, S. Visacro, (2012), Assessing events of upward lightning measured at Morro do Cachimbo Station. 31st International Conference on Lightning Protection (ICLP), Vienna, 2012.

Austin, P. M., and A. C. Bemis (1950), A quantitative study of the "bright band" in radar precipitation echoes, J. Meteor., 7, 145-151.

Azadifar, M., M. Paolone, D. Pavanello, F. Rachidi, C. Romero, and M. Rubinstein (2014), An update on the instrumentation of the Säntis Tower in Switzerland for lightning current measurements and obtained results, in CIGRE International Colloquium on Lightning and Power Systems, Lyon, France.

Azadifar, M., F. Rachidi, M. Rubinstein, V. A. Rakov, M. Paolone, D. Pavanello, \& S. Metz (2016a), Fast initial continuous current pulses versus return stroke pulses in towerinitiated lightning, J. Geophys. Res. Atmos., 121, 6425-6434, doi:10.1002/2016JD024900.

Azadifar, M., F. Rachidi, M. Rubinstein, M. Paolone, G. Diendorfer, H. Pichler, W. Schulz, D. Pavanello, and C. Romero (2016b), Evaluation of the performance characteristics of the European Lightning Detection Network EUCLID in the Alps region for upward negative flashes using direct measurements at the instrumented Säntis Tower, J. Geophys. Res. Atmos., 121, 595-606, doi:10.1002/2015JD024259.

Azadifar M, Lagasio M, Fiori E, Rachidi F, Rubinstein M, Procopio R. (2016c) Occurrence of downward and upward flashes at the Säntis tower: Relationship with $-10^{\circ} \mathrm{C}$ temperature altitude. European Electromagnetics International Symposium (EUROEM), London, 2016.

Barnes, H. C., and R. A. Houze Jr. (2014), Precipitation hydrometeor type relative to the mesoscale airflow in mature oceanic deep convection of theMadden-Julian Oscillation, J. Geophys. Res. Atmos.,119, 13,990-14,014, doi:10.1002/2014JD022241.

Bazelyan, E.M. and Y.P. Raizer, (2000), Lightning Physics and Lightning Protection, Bristol IOP Publishing,

Becerra, M. (2014). Corona discharges and their effect on lightning attachment revisited: Upward leader initiation and downward leader interception, Atmos. Res. 149 (2014) 316-323 
Berger, K., (1967), Novel observations on lightning discharges: Results of research on Mount San Salvatore, J. Franklin Inst., 283, 478-525, doi:10.1016/0016-0032(67)90598-4.

Besic, N., Figueras i Ventura, J., Grazioli, J., Gabella, M., Germann, U, and A. Berne, (2016), Hydrometeor classification through statistical clustering of polarimetric radar measurements: a semi-supervised approach, Atmos. Meas. Tech., 9, 4425-4445, 2016 doi: 10.5194/amt-9-4425-2016

Biggerstaff, M.I. and S.A. Listemaa, (2000), An Improved Scheme for Convective/Stratiform Echo Classification Using Radar Reflectivity, J. Appl. Meteor., 39, 2129-2150

Brook, M., Nakano, M., Krehbiel, P. and Takeuti, T, 1982. The electrical structure of the Hokuriku winter thunderstorms, J.Geophys. Res. 87, 1207-1215.

Coleman, L. M., T. C. Marshall, M. Stolzenburg, T. Hamlin, P. R. Krehbiel, W. Rison, and R. J. Thomas, (2003), Effects of charge and electrostatic potential on lightning propagation, J. Geophys. Res., 108(D9), 4298, doi:10.1029/2002JD002718

Coleman, L. M., M. Stolzenburg, T. C. Marshall, and M. Stanley (2008), Horizontal lightning propagation, preliminary breakdown, and electric potential in New Mexico thunderstorms, J. Geophys. Res., 113, D09208, doi:10.1029/2007JD009459

Cummins, K. L. and M. J. Murphy (2009), An overview of lightning location systems: History, techniques, and data uses with an in-depth look at the U.S. NLDN, IEEE, Trans. Electromagn. Compat., 51, 499-518

Diendorfer, G., H. Pichler, and M. Mair (2009), Some parameters of negative upward initiated lightning to the Gaisberg Tower (2000-2007), IEEE Trans. Electromagn. Compat., 51, 443-452.

Dolan, B. and S.A. Rutledge, (2009), A Theory-Based Hydrometeor Identification Algorithm for X-Band Polarimetric Radars. J. Atmos. Oceanic Technol., 26, 2071-2088, https://doi.org/10.1175/2009JTECHA1208.1

Duda, J. D. and W. A. Gallus (2010), Spring and Summer Midwestern Severe Weather Reports in Supercells Compared to Other Morphologies, Wea. Forecasting, 25, 190206. doi: http://dx.doi.org/10.1175/2009WAF2222338.1

Dye, J.E. and J.C. Willett, 2007: Observed Enhancement of Reflectivity and the Electric Field in Long-Lived Florida Anvils. Mon. Wea. Rev., 135, 3362-3380, https://doi.org/10.1175/MWR3484.1

Edens, H. E., et al. (2012), VHF lightning mapping observations of a triggered lightning flash, Geophys. Res. Lett., 39, L19807, https://doi.org/10.1029/2012GL053666

Field, P. R., 1999: Aircraft observations of ice crystal evolution in an altostratus cloud. J. Atmos. Sci., 56, 1925-1941.

Figueras i Ventura, J., Pineda, N., Besic, N., Grazioli, J., Hering, A., van der Velde, O. A., Romero, D., Sunjerga, A., Mostajabi, A., Azadifar, M., Rubinstein, M., Montanyà, J., Germann, U., and Rachidi, F.: Polarimetric radar characteristics of lightning initiation and propagating channels, Atmos. Meas. Tech., 12, 2881-2911, https://doi.org/10.5194/amt-12-2881-2019, 2019.

Flache, D., Rakov, V. A., Heidler, F., Zischank, W., \& Thottappillil, R. (2008). Initial-stage pulses in upward lightning: Leader/return stroke versus M-component mode of charge transfer to ground. Geophys. Res. Lett., 35, L13812.

https://doi.org/10.1029/2008GL034148 
Foley, A.M., Leahy, P.G., Marvuglia, A., McKeogh, E.J., (2012), Current Methods and Advances in Forecasting of Wind Power Generation. Renewable Energy, 37, 1-8.

Fuchs, B. R., E. C. Bruning, S. A. Rutledge,L. D. Carey, P. R. Krehbiel, and W. Rison (2016), Climatological analyses of LMA data with an open-source lightning flashclustering algorithm, J. Geophys. Res. Atmos., 121, 8625-8648, https://doi.org/10.1002/2015JD024663

Germann, U., Boscacci, M., Gabella, M., \& Sartori, M. (2015). Peak performance: Radar design for prediction in the Swiss Alps, Meteorological Technology International, 4245.

Grazioli, J., Tuia, D., and Berne, A.: Hydrometeor classification from polarimetric radar measurements: a clustering approach, Atmos. Meas. Tech., 8, 149-170, doi:10.5194/amt-8-149-2015, 2015.

Helmus, J J and S. M. Collis (2016), The Python ARM Radar Toolkit (Py-ART), a Library for Working with Weather Radar Data in the Python Programming Language. Journal of Open Research Software, 4: e25, DOI: http://dx.doi.org/10.5334/jors.119

Hill, J. D., J. Pilkey, M. A. Uman, D. M. Jordan, W. Rison, and P. R. Krehbiel (2012), Geometrical and electrical characteristics of the initial stage in Florida triggered lightning, Geophys. Res. Lett., 39, L09807, doi:10.1029/2012GL051932.

Hill, J. D., J. Pilkey, M. A. Uman, D. M. Jordan, W. Rison, P. R. Krebhiel, M. I Biggerstaff, P. Hyland, and R. Blakeslee (2013), Correlated lightning mapping array and radar observations of the initial stages of three sequentially triggered Florida lightning discharges, J. Geophys. Res. Atmos., 118, 8460-8481, https://doi.org/10.1002/jgrd.50660

Hobbs, P. V., S. Chang, and J. D. Locatelli, (1974), The dimensions and aggregation of ice crystals in natural clouds. J. Geophys. Res., 79, 2199-2206

Houze, R. A., Jr. (1997), Stratiform precipitation in regions of convection: A meteorological paradox?, Bull. Am. Meteorol. Soc., 78(10), 2179-2196.

Houze, R. A., Jr., and S. Medina (2005), Turbulence as a mechanism for orographic precipitation enhancement, J. Atmos. Sci., 62(10), 3599-3623.

Jiang, R., Qie, X., Wu, Z., Wang, D., Liu, M., Lu, G., \& Liu, D. (2014). Characteristics of upward lightning from a 325-m-tall meteorology tower. Atmos. Res., 149, 111-119. https://doi.org/10.1016/j.atmosres.2014.06.007

Jirak, I.L., W.R. Cotton, and R.L. McAnelly, (2003), Satellite and Radar Survey of Mesoscale Convective System Development. Mon. Wea. Rev., 131, 2428-2449, https://doi.org/10.1175/1520-0493(2003)131<2428:SARSOM>2.0.CO;2

Kasemir, H. W., A contribution to the electrostatic theory of a lightning discharge, J. Geophys. Res., 65, 1873-1878, 1960.

Krehbiel, P. R., (1976), The electrical structure of thunderstorms, in The Earth's Electrical Environment, edited by E. P. Krider and R. G. Robie, pp. 90- 113, Natl. Acad. Press, Washington, D.C., 1986.

Kumjian, M. R., (2013), Principles and applications of dual-polarization weather radar. Part II: Warm and cold season applications. J. Oper. Meteor., 1, 243-264, doi:10.15191/nwajom.2013.0120. 
Li, D., M. Azadifar, F. Rachidi, M. Rubinstein, M. Paolone, D. Pavanello, S. Metz, Q. Zhang, Z. Wang, "On Lightning Electromagnetic Field Propagation along an Irregular Terrain", IEEE Transactions Electromagn. Compat., Vol. 58, No 1, pp. 161-171, 2016.

Locatelli, J. D., and P. V. Hobbs, (1974), Fall speeds and masses of solid precipitation particles. J. Geophys. Res., 79, 2185-2197

Lu, W., L. Chen, Y. Zhang, Y. Ma, Y. Gao, Q. Yin, S. Chen, Z. Huang, and Y. Zhang (2012), Characteristics of unconnected upward leaders initiated from tall structures observed in Guangzhou, J. Geophys. Res., 117, D19211, doi:10.1029/2012JD018035

MacGorman, D.R., Rust, W.D.,1998. The Electrical Nature of Storms, 422 pp., Oxford Univ. Press, Oxford.

MacGorman D., S. Waugh, M. Biggerstaff, J. Pilkey, M. Uman, T. Ngin, W. Gamerota, D. Jordan, (2014), Coordinated LMA, Balloon-borne Electric Field, and Polarimetric Radar Observations of a Triggered Lightning Flash at Camp Blanding, FL. 23rd International Lightning Detection Conference, Tucson, Arizona, USA

Maddox, R. A., (1980), Mesoscale convective complexes. Bull. Amer. Meteor. Soc., 61, 1374-1387.

Maddox, R. A., (1983), Large-scale meteorological conditions associated with midlatitude, mesoscale convective complexes. Mon. Wea. Rev., 111, 126-140.

Manoochehrnia P. Schulz W. Rachidi F. Rubinstein M., (2008), Lightning statistics in the regions of Saentis and St.chrischona towers in Switzerland. 29th International Conference on Lightning Protection, Uppsala, Sweden

Mansell, E. R., D. R. MacGorman, C. L. Ziegler, and J. M. Straka (2002), Simulated three dimensional branched lightning in a numerical thunderstorm model, J. Geophys Res., 107, 4075, doi:10.1029/2000JD000244.

Marshall, T. C., M. Stolzenburg, P. R. Krehbiel, N. R. Lund, and C. R. Maggio (2009), Electrical evolution during the decay stage of New Mexico thunderstorms, J. Geophys. Res., 114, D02209, doi:10.1029/2008JD010637.

Marshall, T. C., and B. Lin (1992), Electricity in dying thunderstorms, J. Geophys. Res., 97, 9913.

Mazur, V., (1989), Triggered lightning strikes to aircraft and natural intracloud discharges, J. Geophys. Res., 94, 3311 -3325,

Mazur, V., X. Shao, and P. R. Krehbiel (1998), "Spider" lightning in intracloud and positive cloud-to-ground flashes, J. Geophys. Res., 103, 19,811-19,822, doi:10.1029/98JD02003

Mazur, V. (2002). Physical processes during development of lightning flashes. Comptes Rendus Physique, 3(10), 1393-1409. https://doi.org/10.1016/S1631-0705(02)01412-3

Mazur, V., (2016), Principles of Lightning Physics (IOP Expanding Physics) IOP Publishing. ISBN-13: 978-0750311533 ISBN-10: 0750311533

Mazur, V., \& Ruhnke, L. H. (2011). Physical processes during development of upward leaders from tall structures. Journal of Electrostatics, 69(2), 97-110. https://doi.org/10.1016/j.elstat.2011.01.003 
Miki, M., T. Miki, A. Asakawa, T. Shindo and S. Yokoyama, (2012). Characteristics of Upward Leaders of Winter Lightning in the Coastal Area of the Sea of Japan, IEEJ Trans. Power Energy 132 (6): 560-567, https://doi.org/10.1541/ieejpes.132.560

Montanyà, J., O. A. van der Velde, V. March, D. Romero, G. Solà, and N. Pineda (2012), High-speed video of lightning and X-ray pulses during the 2009-2010 observation campaigns in northeastern Spain, Atmos. Res., 117, 91-98.

Montanyà, J., O. van der Velde, and E. R. Williams (2014), Lightning discharges produced by wind turbines, J. Geophys. Res. Atmos., 119, 1455-1462, doi:10.1002/2013JD020225.

Moore, C. B., and B. Vonnegut (1977), The thundercloud, in Lightning, vol. 1, edited by R. H. Golde, p. 51, Elsevier, New York.

Mostajabi A., A., Sunjerga M. Azadifar, A. Smorgonskiy, M. Rubinstein, F. Rachidi, G. Diendorfer (2018), On the Impact of Meteorological Conditions on the Initiation of Upward Lightning Flashes from Tall Structures, 34th International Conference on Lightning Protection (ICLP), doi:10.1109/ICLP.2018.8503310

Nag, A., V. A Rakov,(2009), Some inferences on the role of lower positive charge region in facilitating different types of lightning. Geophys. Res. Lett., 36, L05815, doi: 10.1029/2008GL036783

Parker, M. D., and R. H. Johnson, (2000): Organizational modes of mid-latitude mesoscale convective systems. Mon. Wea. Rev.,128, 3413-3436

Pawar, S. D., and A. K. Kamra (2007), End-of-storm oscillation in tropical air mass thunderstorms, J. Geophys. Res., 112, D03204, doi:10.1029/2005JD006997.

Pichler, H., G. Diendorfer, and M. Mair (2010), Some parameters of correlated current and radiated field pulses from lightning to the Gaisberg Tower, IEEJ Trans. Electr. Electron. Eng., 5, 8-13, doi:10.1002/tee.20486.

Pilkey, J. T., et al. (2013), Rocket-and-wire triggered lightning in 2012 tropical storm Debby in the absence of natural lightning, J. Geophys. Res. Atmos., 118, 13,158-13,174, doi:10.1002/2013JD020501.

Pineda, N., J. Montanyà, A. Salvador, O.A. van der Velde, J.A. López, (2018), Thunderstorm characteristics favouring downward and upward lightning to wind turbines, Atmos.Res. 214: 46-63, https://doi.org/10.1016/j.atmosres.2018.07.012

Pineda, N., J. Bech, J. Montanyà, E. Casellas, D. Romero, S. González, (2018), Meteorological aspects of winter upward lightning from an instrumented tower in the Pyrenees, 34th International Conference on Lightning Protection (ICLP), doi: 10.1109/ICLP.2018.8503271

Poelman, D.R., Schulz, W., Diendorfer, G., Bernardi, M., (2016), The European lightning location system EUCLID - Part 2: Observations. Nat. Hazards Earth Syst. Sci., 16, 607-616, 2016. doi:10.5194/nhess-16-607-2016

Proctor, D., R. Uytenbogaardt, and B. Meredith (1988), VHF radio pictures of lightning flashes to ground, J. Geophys. Res., 93, 12,683-12,727, doi:10.1029/JD093iD10p12683.

Qie, X., R. Jiang, C. Wang, J. Yang, J. Wang, and D. Liu (2011), Simultaneously measured current luminosity and electric field pulses in a rockettriggered lightning flash, J. Geophys. Res., 116, D10102, doi:10.1029/2010JD015331. 
Rachidi, F., Rubinstein, M., Montanyà, J., Bermudez, J.L., Rodriguez, R., Solà, G., Korovkin, N., 2008. A review of current issues in lightning protection of new generation wind turbine blades, IEEE Trans. Ind. Electron., vol. 55, no. 6, pp. 2489-2496, doi:10.1109/TIE.2007.896443.

Rakov, V. A., and M. A. Uman, 2003: Lightning: Physics and Effects. Cambridge University Press, $687 \mathrm{pp}$.

Rison, W., Thomas, R.J., Krehbiel, P.R., Hamlin, T., Harlin J., 1999. A GPS-based threedimensional lightning mapping system: Initial observations in central New Mexico, J. Geophys. Res., 26, 3573-3576.

Romero, C., M. Paolone, M. Rubinstein, F. Rachidi, A. Rubinstein, G. Diendorfer, W. Schulz, B. Daout, A. Kälin, and P. Zweiacker (2012), A system for the measurements of lightning currents at the Säntis Tower, Electr. Power Syst. Res., 82, 34-43.

Romero, C., Rachidi, F., Rubinstein, M., Paolone, M., Rakov, V. A., \& Pavanello, D. (2013). Positive lightning flashes recorded on the Säntis tower from May 2010 to January 2012. J. Geophys. Res. Atmos., 118, 12,879-12,892. https://doi.org/10.1002/2013JD020242

Rust, W. D., D. R. MacGorman, E. C. Burning, S. A. Weiss, P. R. Krehbiel, R. J. Thomas, W. Rison, T. Hamlin, and J. Harlin (2005), Inverted-polarity electrical structures in thunderstorms in the Severe Thunderstorm Electrification and Precipitation Study (STEPS). Atmos. Res., 76, 247-271.

Saito M, Ishii M, Fujii F, Matsui M. Seasonal variation of frequency of high current lightning discharges observed by JLDN. IEEJ Trans. Power Energy 2012; 132(6):536-541.

Saraiva, A. C. V., Campos, L. Z. S., Williams, E. R., Zepka, G. S., Alves, J., Pinto, O. Jr., ... Blakeslee, R. J. (2014). High-speed video and electromagnetic analysis of two natural bipolar cloud-to-ground lightning flashes. Journal of Geophysical Research: Atmospheres, 119, 6105-6127. https://doi.org/10.1002/2013JD020974

Saunders, C. P. R., H. Bax-Norman, C. Emersic, E. E. Avila, and N. E. Castellano (2006), Laboratory studies of the effect of cloud conditions on graupel/crystal charge transfer in thunderstorm electrification, Q. J. R. Meteorol. Soc., 132, 2653-2673, doi:10/1256/qj.05.218.

Schultz, C. J., Lang, T. J., Bruning, E. C., Calhoun, K. M., Harkema, S., \& Curtis, N. (2018). Characteristics of lightning within electrified snowfall events using lightning mapping arrays. J. Geophys. Res. Atmos., 123. https://doi.org/10.1002/2017JD027821

Schulz, W., Diendorfer, G., Pedeboy, S., and Poelman, D. R. (2016), The European lightning location system EUCLID - Part 1: Performance analysis and validation, Nat. Hazards Earth Syst. Sci., 16, 595-605, https://doi.org/10.5194/nhess-16-595-2016, 2016.

Schuur, T.J. \& Rutledge, S.A. (2000a), Electrification of stratiform regions in mesoscale convective systems. Part I: An observational comparison of symmetric and asymmetric MCSs, J. Atmosph. Sci., 57, 1961-1982.

Schuur, T.J. \& Rutledge, SA. (2000b), Electrification of Stratiform regions in Mesoscale Convective Systems. Part II: Two-dimensional numerical model simulations of a symmetric MCS. J. Atmos. Sci., 57, 1983-2000.

Shao, X., Krehbiel, P., 1996. The spatial and temporal development of intracloud lightning, J. Geophys. Res., 101, 26,641-26,668, doi:10.1029/ 96JD01803 
Shao, X. M., C. T. Rhodes, and D. N. Holden (1999), RF radiation observations of positive cloud-to-ground flashes, J. Geophys. Res., 104(D8), 9601-9608, doi:10.1029/1999JD900036.

Shi, D., Wang, D., Wu, T., Thomas, R. J.,Edens, H. E., Rison, W., Takagi, N., \& Krehbiel, P. R. (2018). Leader polarity-reversal feature and charge structure of three upward bipolar lightning flashes. . J. Geophys. Res. Atmos., 123, 9430-9442. https://doi.org/10.1029/2018JD028637

Shindo, T., Miki, T., Saito, M., Asakawa, A., Motoyama, H., Ishii, M., Fujisawa, A. (2015). Meteorological conditions and occurrence of upward lightning at high structures. IEEJ Trans. Power Energy 135(6), 417-418. https://doi.org/10.1541/ieejpes.135.417

Smorgonskiy, A., F. Rachidi, M. Rubinstein, G. Diendorfer, W. Schulz, (2013), On the proportion of upward flashes to lightning research towers, Atmos. Res. 129-130 (2013) 110-116

Smorgonskiy, A., Tajalli, A., Rachidi, F., Rubinstein, M., Diendorfer, G., Pichler, H., 2015. An analysis of the initiation of upward flashes from tall towers with particular reference to Gaisberg and Säntis Towers. J. Atmos. Terr. Phys. 136 (A), 46-51.

Steiner, M., and R. A. Houze Jr., and S. E. Yuter, 1995: Climatological characterization of three-dimensional storm structure from operational radar and rain gauge data. J. Appl. Meteor., 34, 1978-2007.

Stolzenburg, M., Marshall, T.C., Rust, W.D., Smull, B.F., 1994. Horizontal distribution of electrical and meteorological conditions across the stratiform region of a mesoscale convective system. Mon. Weather Rev. 122, 1777-1797.

Stolzenburg, M.. Marshall, T.C 2008, Charge Structure and Dynamics in Thunderstorms, Space Sci Rev, doi: 10.1007/s11214-008-9338-z

Takahashi, T., (1978) Riming electrification as a charge generation mechanism in thunderstorms. J. Atmos. Sci., 35, 1536-1548.

Thomas, R. J., P. R. Krehbiel, W. Rison, T. Hamlin, J. Harlin, and D. Shown (2001), Observations of VHF source powers radiated by lightning, Geophys. Res. Lett., 28, 143-146.

Thomas, R., Krehbiel, P.R., Rison,W., Hunyady, S.J.,Winn, W.P., Hamlin, T., Harlin, J., 2004. Accuracy of the lightning mapping array. J. Geophys. Res. 109, D14207. doi:10.1029/2004JD004549

van der Velde, O.A., Montanyà, J., 2013. Asymmetries in bidirectional leader development of lightning flashes, J. Geophys. Res. Atmos., 118, doi:10.1002/2013JD020257

Wang, D., and N. Takagi (2012), Characteristics of winter lightning that occurred on a windmill and its lightning protection tower in Japan, IEEJ Trans. Power Energy, 132(6), https://doi.org/10.1541/icejpes 132.568

Wang, D., N. Takagi, T. Watanabe, H. Sakurano, and M. Hashimoto (2008), Observed characteristics of upward leaders that are initiated from a windmill and its lightning protection tower, Geophys. Res. Lett., 15, L02803, https://doi.org/10.1029/2007GL032136

Wang, D., T. Wu, N. Takagi, (2018), Charge Structure of Winter Thunderstorm in Japan: a Review and an Update IEEJ Trans. Power Energy 138 (5): 310-314 https://doi.org/10.1541/ieejpes.138.310 
Warner, T. A. (2012). Observations of simultaneous upward lightning from multiple tall structures. Atmos. Res., 117, 45-54. https://doi.org/10.1016/j.atmosres.2011.07.004

Warner, T. A., T. J. Lang, and W. A. Lyons (2014), Synoptic scale outbreak of self-initiated upward lightning (SIUL) from tall structures during the central U.S. blizzard of 1-2 February 2011, J. Geophys. Res. Atmos., 119, 9530-9548, doi:10.1002/2014JD021691

White, A.B., D.J. Gottas, E.T. Strem, F.M. Ralph, and P.J. Neiman, 2002: An Automated Brightband Height Detection Algorithm for Use with Doppler Radar Spectral Moments. J. Atmos. Oceanic Technol., 19, 687-697, https://doi.org/10.1175/15200426(2002)019<0687:AABHDA>2.0.CO;2

Wiens, K.C., Rutledge, S.A., \& Tessendorf, S.A. (2005) The 29 June 2000 supercell observed during STEPS. Part II: Lightning and charge structure. J. Atmos. Sci., 62, 4151-4177.

Williams, E. R. (1985), Large-scale separation in thunderclouds, J. Geophys. Res., 90, 60136025, doi:10.1029/JD090iD04p06013

Williams, E.R. (1989), The tripole structure of thunderstorms. J. Geophys. Res.. 94. D11. $13,151-13,167$.

Williams, E., R. Zhang, and D. Boccippio (1994), Microphysical growth state of ice particles and large-scale electrical structure of clouds, J. Geophys. Res., 99, 10,787.

Williams, E. R., and S. Heckman (2012), Polarity asymmetry in lightning leaders: The evolution of ideas on lightning behavior from strikes to aircraft, J. AerospaceLab, (5), $1-8$.

Wu, T., D. Wang, W. Rison, R. J. Thomas, H. E. Edens, N. Takagi, and P. R. Krehbiel (2017), Corona discharges from a windmill and its lightning protection tower in winter thunderstorms, J. Geophys. Res. Atmos., 122, 4849-4865, https://doi.org/10.1002/2016JD025832

Yoshida, S., C. J. Biagi, V. A. Rakov, J. D. Hill, M. V. Stapleton, D. M. Jordan, M. A. Uman, T. Morimoto, T. Ushio, and Z.-I. Kawasaki (2010), Three-dimensional imaging of upward positive leaders in triggered lightning using VHF broadband digital interferometers, Geophys. Res. Lett., 37, L05805, doi:10.1029/2009GL042065.

Yuan, S., Jiang, R., Qie, X., Wang, D., Sun, Z., \& Liu,M. (2017). Characteristics of upward lightning on the Beijing $325 \mathrm{~m}$ meteorology tower and corresponding thunderstorm conditions. Journal of Geophysical Research: Atmospheres, 122. https://doi.org/10.1002/2017JD027198

Zhou, H., G. Diendorfer, R. Thottappillil, H. Pichler, and M. Mair, (2012), Characteristics of upward positive lightning flashes initiated from the Gaisberg Tower, 1. Geophys. Res., 117, D06110, doi:10.1029/201 IJD016903, 2012.

Zhou, H., G. Diendorfer, R. Thottappillil, H. Pichler, M. Mair, (2014), The influence of meteorological conditions on upward lightning initiation at the Gaisberg Tower, 2014 International Conference on Lightning Protection (ICLP), 1162-1165, doi:10.1109/ICLP.2014.6973303 


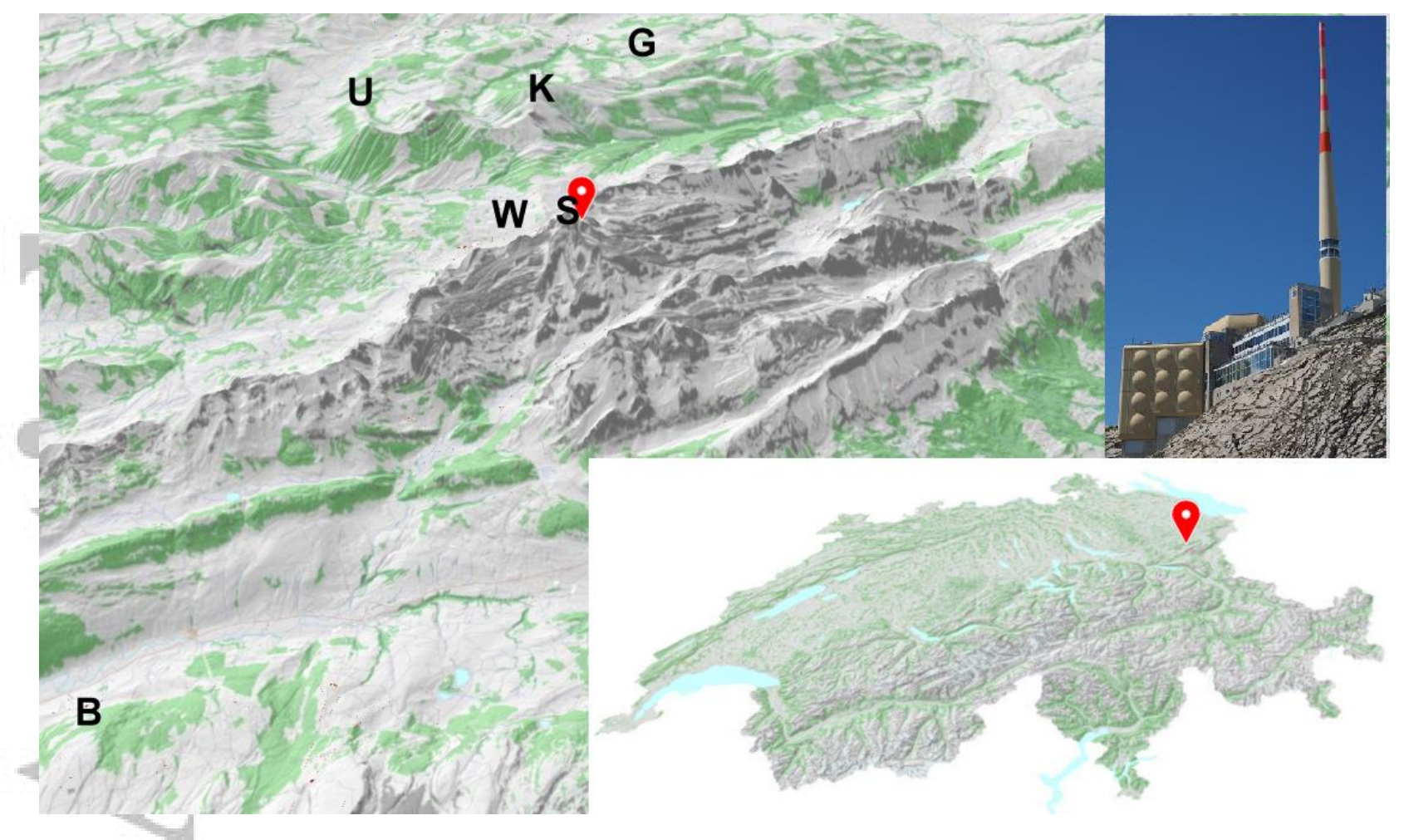

Figure 1. Säntis Tower $\left(47^{\circ} 14^{\prime} 57^{\prime \prime} \mathrm{N}\right.$ and $\left.9^{\circ} 20^{\prime} 32^{\prime \prime} \mathrm{E}\right)$ at the Säntis Mountain (2,505 m ASL), Northeastern Switzerland. The measurement stations, Schwägalp (W), Kronberg (K), Urnäsch (U), Gonten (G), STBO (B) and Säntis (S), were deployed in the vicinity of the Säntis Tower, at distances ranging from $100 \mathrm{~m}$ to $11 \mathrm{~km}$. Source: Federal Office of Topography (Swisstopo) and picture by maxpixel.net

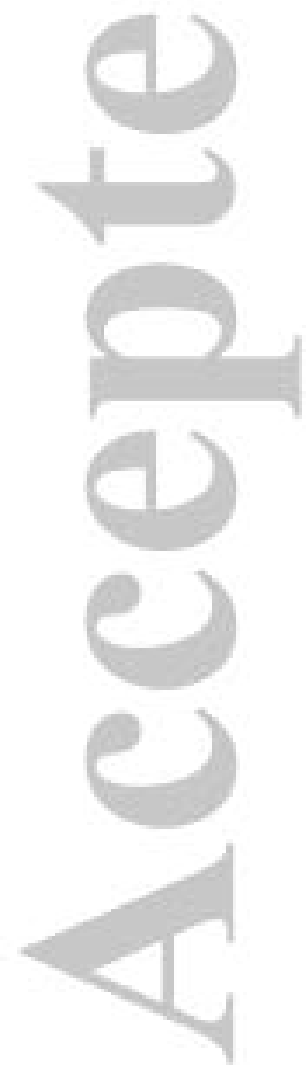


a)
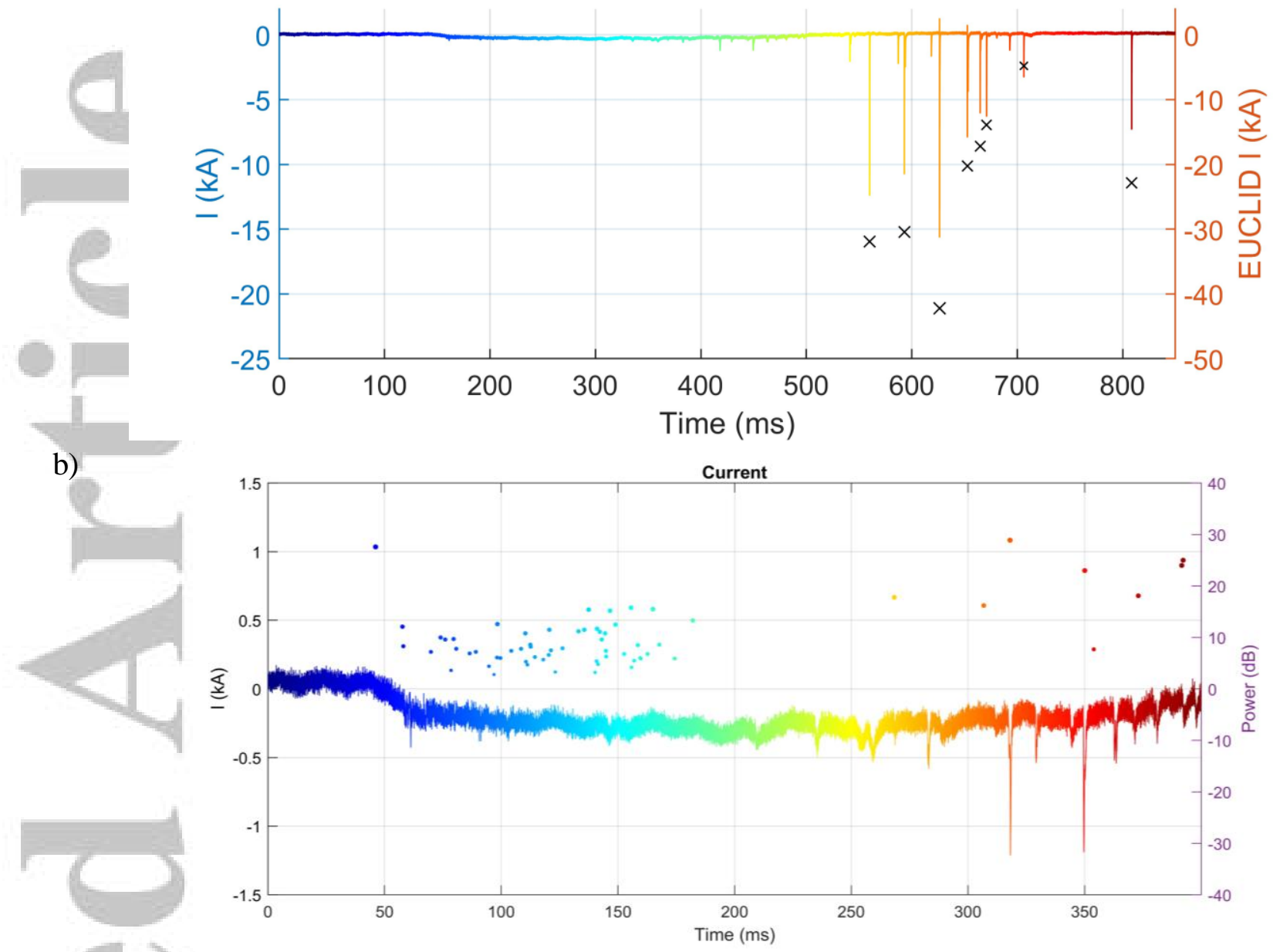

Figure 2. Waveform associated with a self-initiated upward lightning (positive leader) occurred on June 29 at 14:06:12 UT (a) Original current waveform. Concurrent EUCLID strokes are presented in this same plot with crosses (secondary axis). Time is relative to the beginning of the measurement of the ICC at the Tower. (b) Expanded view of the initial continuous current associated with the upward positive leader phase, together with the LMA VHF sources (power in $\mathrm{dBW}$ ) 


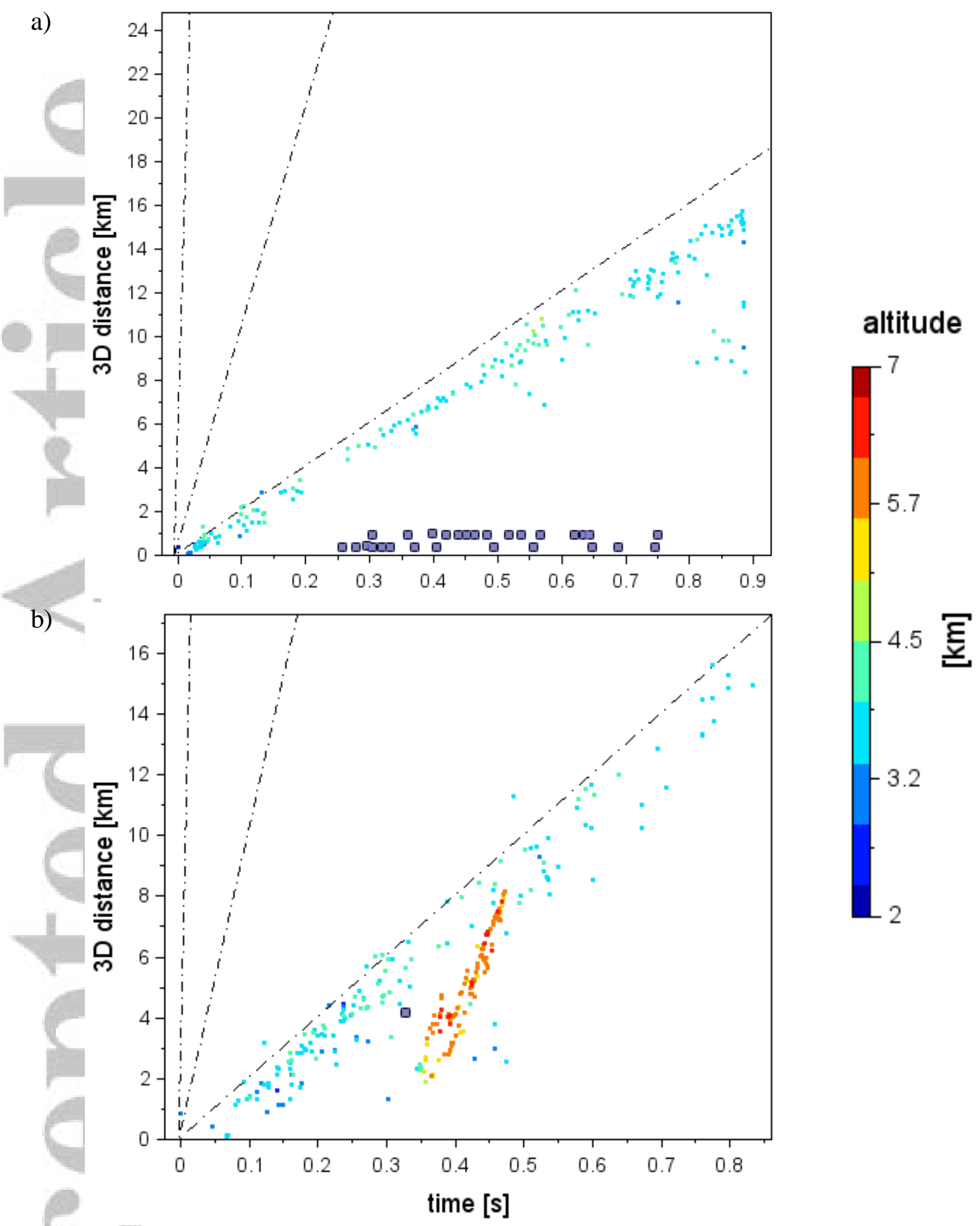

Figure 3. Time-distance graphs of sources mapped by the Lightning Mapping Array, of (a) event \#9 2017/06/29 15:45:52 UT and (b) event \#11 2017/06/29 15:50:02 UT. Reference dashed lines indicate slopes corresponding to speeds of $2 \cdot 10^{4} \mathrm{~ms}^{-1}, 10^{5} \mathrm{~ms}^{-1}$, and $10^{6} \mathrm{~ms}^{-1}$, characteristic horizontal speeds for positive, negative and very fast negative leaders respectively. The reference location for the distance is the initiation point of each flash (at $\mathrm{t}=0$ ). Black square marks are low-frequency sources detected by EUCLID (intracloud or cloud-to-ground strokes). 


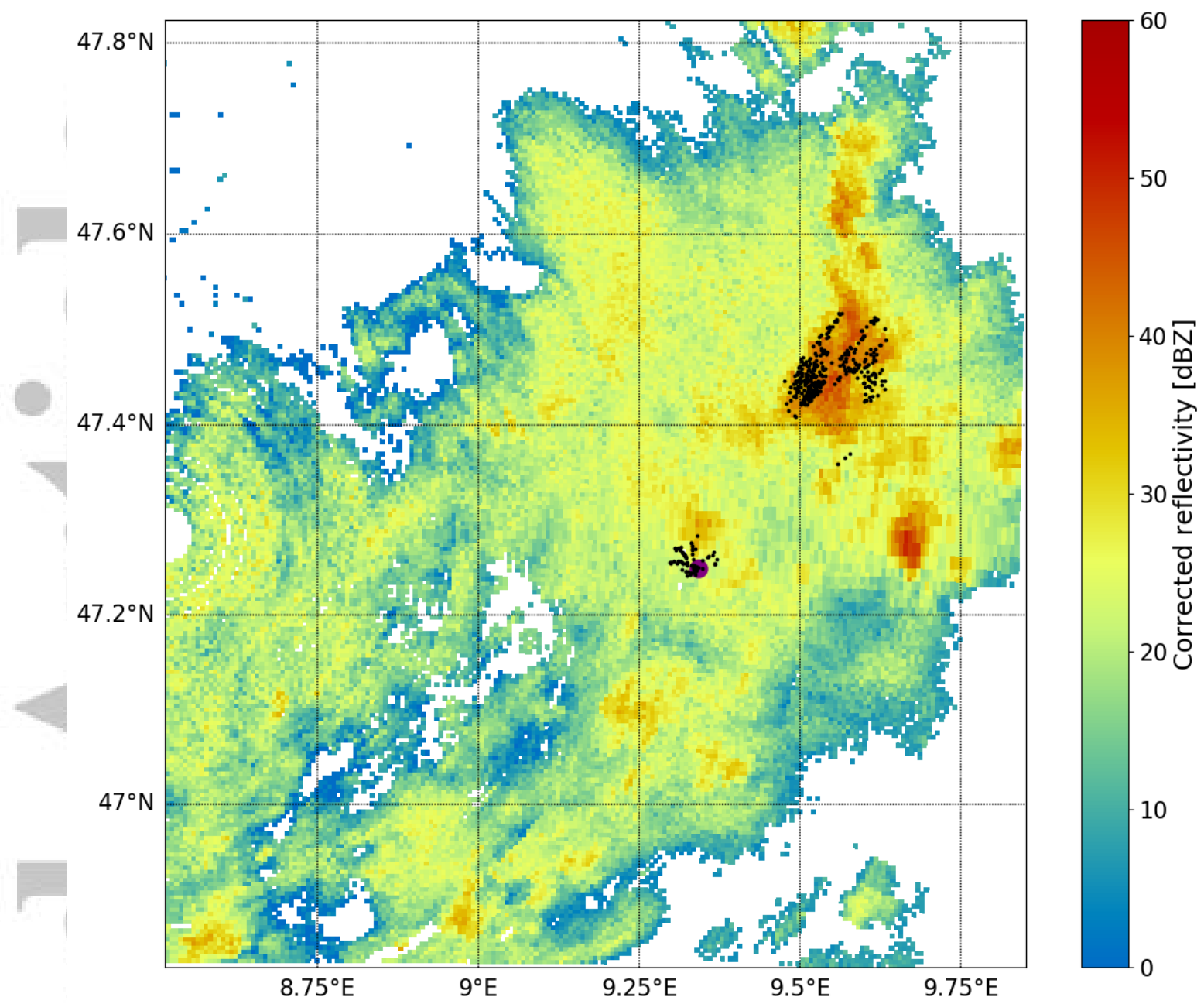

Figure 4. Basemap of corrected reflectivity (Constant Altitude Plan Position Indicator, CAPPI at $4 \mathrm{~km}$ height ASL) over a 100-km x 100-km domain approx., with overlayed LMA VHF sources of the MCS crossing the Säntis, June 29, 2017, time span 14:05-14:10 UT. The purple circle corresponds to the Säntis Tower $\left(47^{\circ} 14^{\prime} 57^{\prime \prime} \mathrm{N}\right.$ and $\left.9^{\circ} 20^{\prime} 32^{\prime \prime} \mathrm{E}\right)$. The Albis radar $\left(47^{\circ} 17^{\prime} 03.71^{\prime \prime} \mathrm{N} 8^{\circ} 30^{\prime} 43.31^{\prime \prime} \mathrm{E}\right)$ being located on the left edge of the image, can be guessed by the concentric rings that remain on the reflectivity field. 


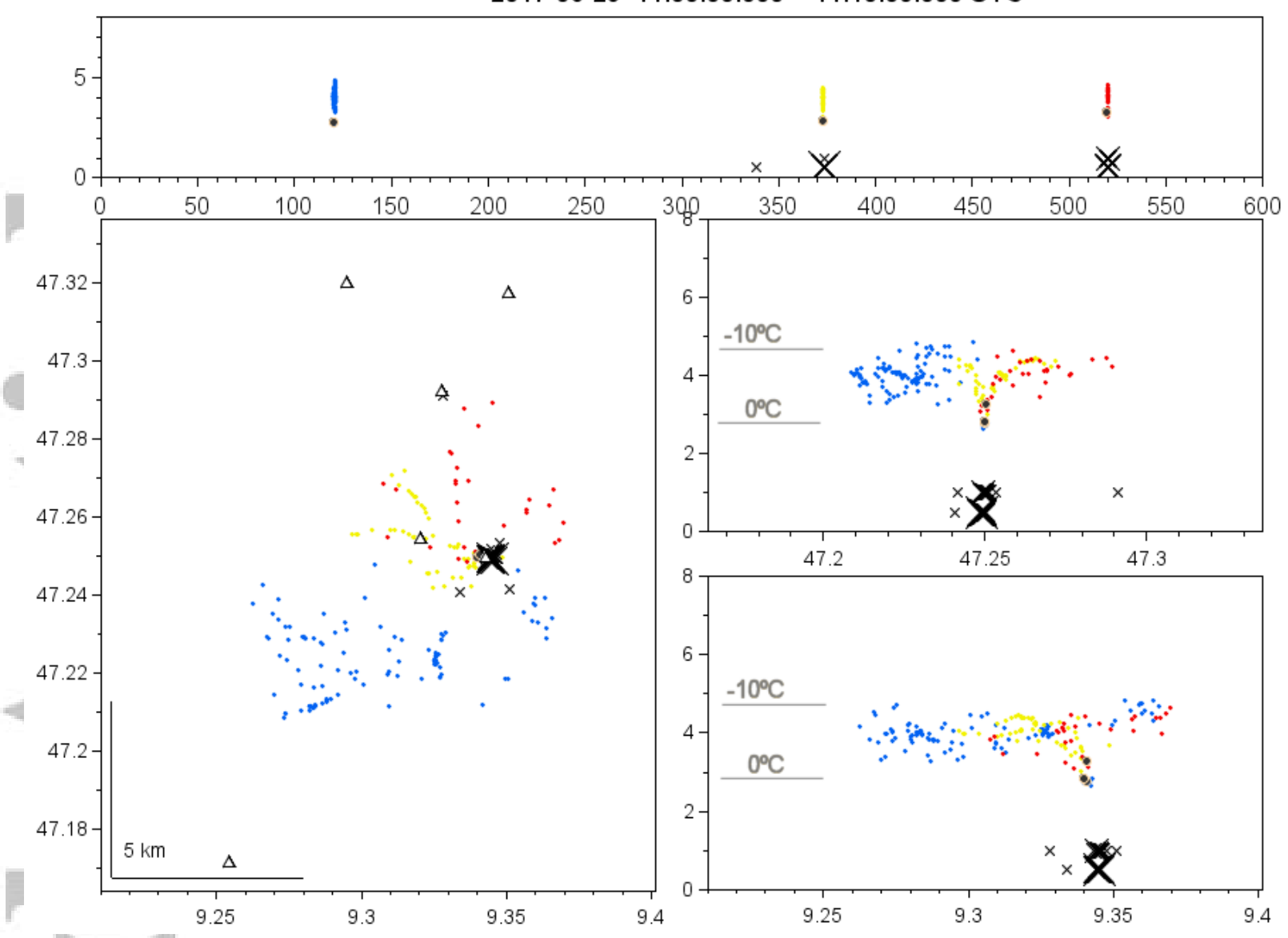

Figure 5. Multipanel display of intracloud lightning activity detected by the LMA over the Säntis Mountain area, 2017/06/29, from 14:00:00 UT to 14:10:00 UT. These ten minutes encompass three UPLs, displayed in different colors, events \#1 (blue) \#2 (yellow) and \#3 (red) in Table 1. Black circles correspond to the initial source in each event. The top panel is altitude above mean sea level (km) versus time (time in seconds regarding the ten-min period). The left panel is a plan view map. Triangles represent LMA stations. The panels at the right show altitude $(\mathrm{km})$ versus latitude (top) and longitude (bottom). Black X marks are low-frequency sources detected by EUCLID (intracloud or cloud-toground strokes), the size being proportional to the detected peak current. EUCLID strokes classified as intracloud are represented arbitrarily at $1 \mathrm{~km}$ height, and CG at $0.5 \mathrm{~km}$. 

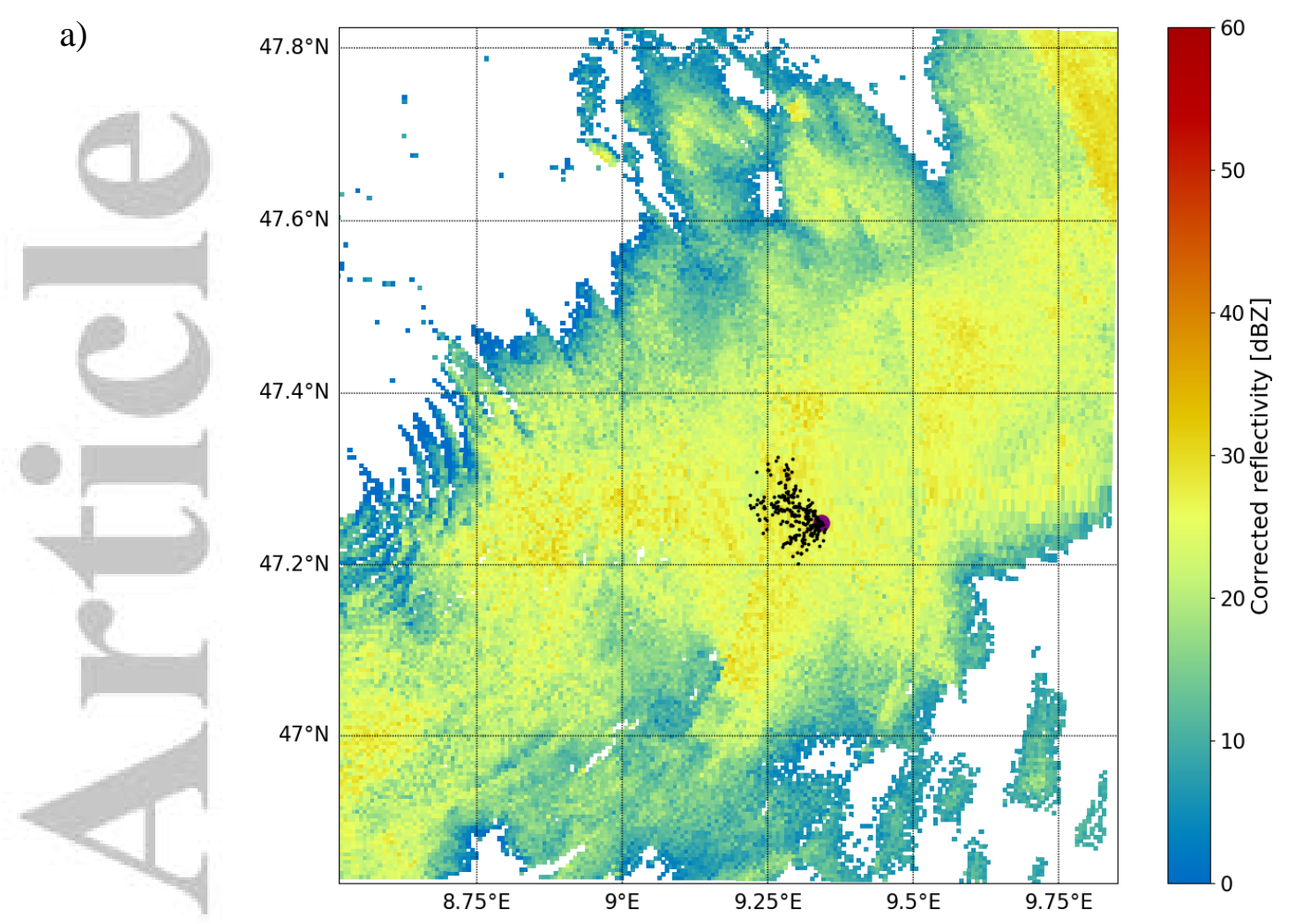

b)

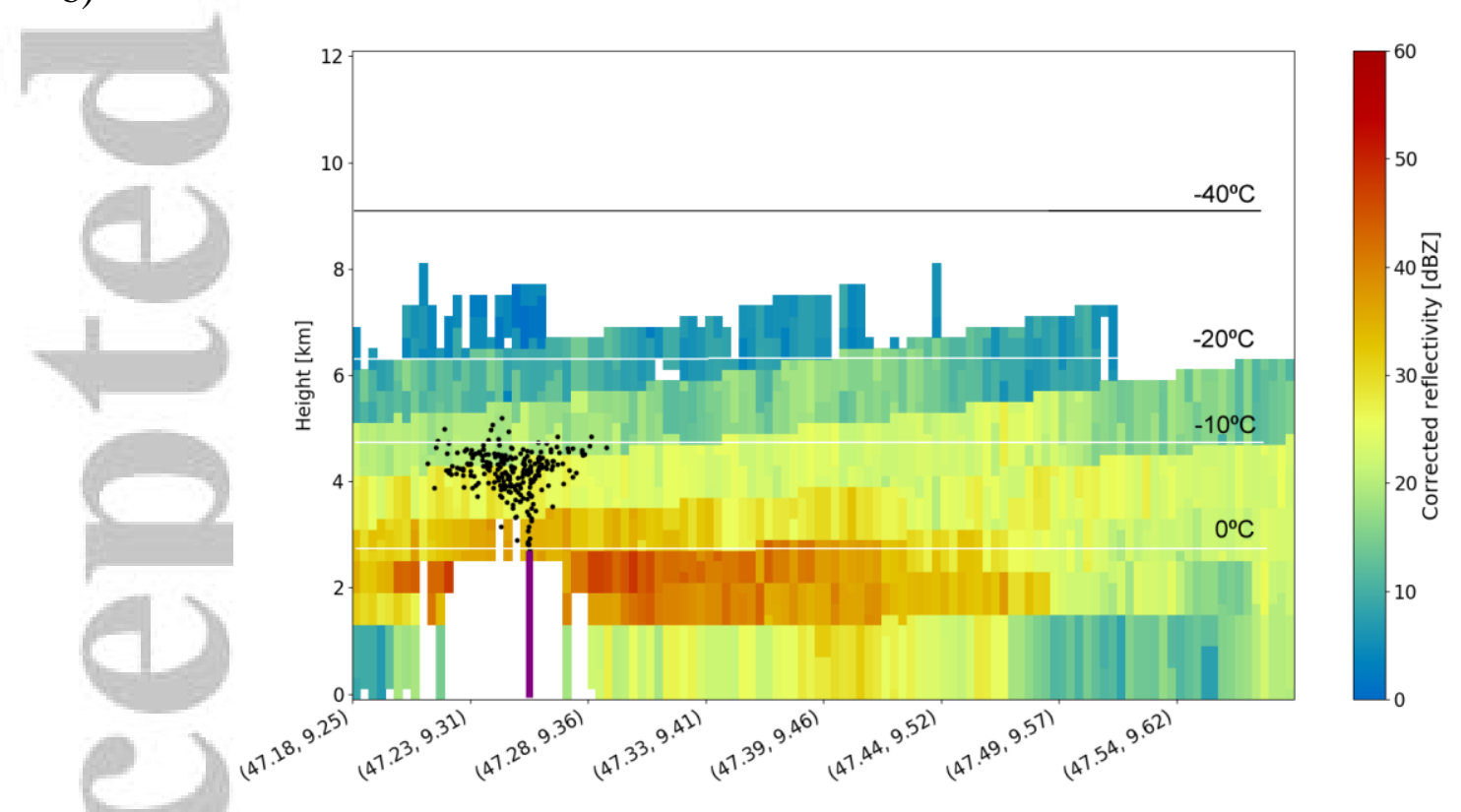

Figure 6. (a) As Figure 4, but for 2017/06/29 at 15:35-15:40 UT (events \#7 and \#8). (b) Vertical cross section on the radar reflectivity volume (XSEC-R). The Säntis Tower (location and height) are represented with a grey column. LMA VHF sources corresponding to events \#7 and \#8 are overlaid, as well as key environmental temperatures $\left(0^{\circ} \mathrm{C},-10^{\circ},-20^{\circ} \mathrm{C}\right.$ and $\left.-40^{\circ} \mathrm{C}\right)$ derived from the COSMO modeloutput soundings from MeteoS wiss. The figures have been plotted using PyART open-source software (Helmus and Collis, 2006) 


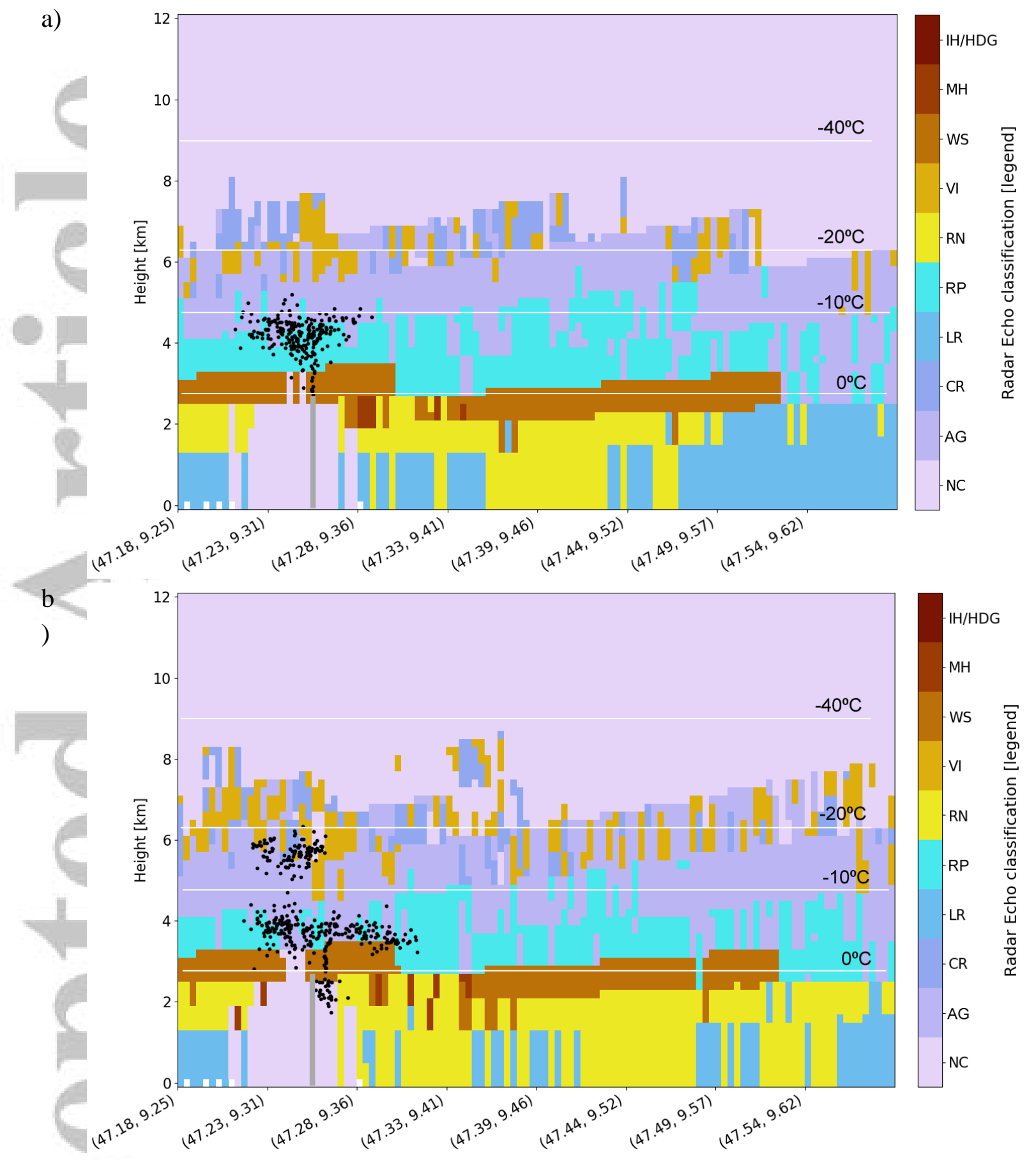

Figure 7 Vertical cross sections (SW-NE) of a) hydrometeor classification products (XSEC-H), 2017/06/29 at 15:35-15:40 UT (events \#7 and \#8). b) 2017/06/29, at 15:50-15:55 (events \#11 and \#12). Hydrometeor classification categories (Besic et al., 2016): IH/HDG - ice hail / high density graupel -, MH - melting hail -, WS - wet snow-, VI - vertically aligned ice-, RN - rain-, RP- rimed ice particles-, LR - light rain-, CR - ice crystals-, AG - aggregates-, NC - not classified/ no data. The Säntis Tower (location and height) are represented with a grey column. The figures have been plotted using Py-ART open-source software (Helmus and Collis, 2006). 




Figure 8. a) As to Figure $6 \mathrm{~b}$ but for 2017/07/10 at 21:15-21:20 UT (encompassing event \#17 21:19:37 UT) b) As Figure 7 but for 2017/07/10 at 21:15-21:20 UT (event \#17, 21:19:37 UT). 

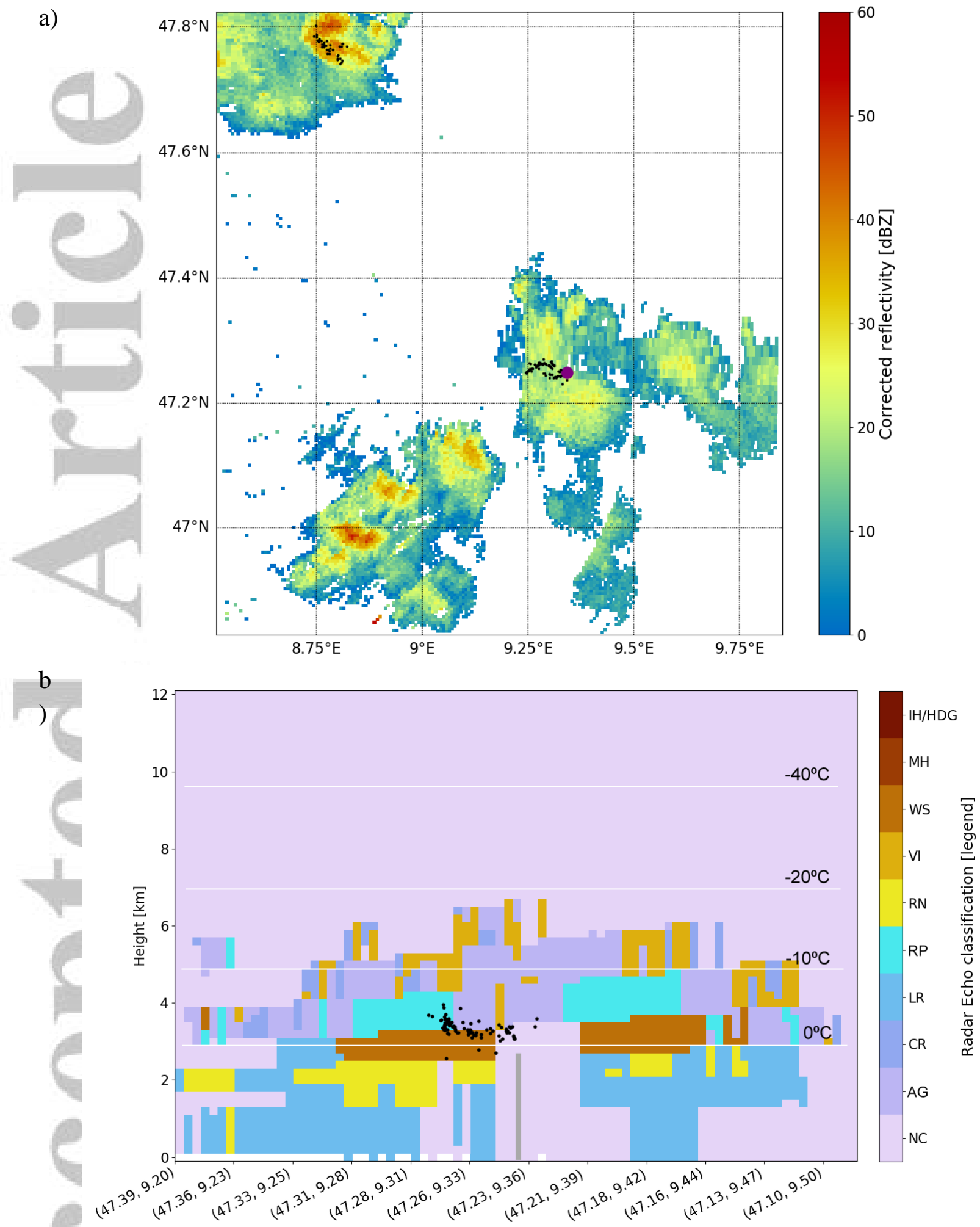

Figure 9. a) As to Figure 4 but for 2017/07/14 at 14:00-14:05 UT (encompassing event \#19, 14:00:02 UT). b) As to Figure 7 but for 2017/07/14 at 14:00-14:05 UT (event \#19, 14:00:12). 
Table 1. Characteristics of nineteen self-initiated upward lightning detected in three different dates. LMA columns depict time, number of sources, time of the first detected source and duration of the event, and upward-propagating leader polarity. Event numbers used through the text are shown in the far-left column. In some cases $\left(^{*}\right)$ an insufficient number of VHF sources were recorded to estimate leader speed (and polarity). The next three columns correspond to Tower measurements, showing the time of the first source, the number of current pulses (above $2 \mathrm{kA}$ ) and the maximum and the average peak current per event. The triggering system at Säntis Tower is based on the current derivative. The system did not trigger in the case of absence of any fast pulse, which seems the case for events \#1, \#11 and \#19. The "delay" column reports the time difference (ms), between the first LMA detection and the first pulse at the Tower (>2kA). EUCLID columns display the number of strokes per event, the intra-cloud/cloud-to-ground counts and maximum peak current (and corresponding stroke).

Event 18 was a bipolar flash. Last columns correspond to wind speed and wind gusts measured at the Säntis weather station (dashes are indicative of missing observations). All times are in Coordinated Universal Time (UT), and are given in the format HH:MM:SS. Local time calculation requires the addition of 2 hours.

\begin{tabular}{|c|c|c|c|c|c|c|c|c|c|c|c|c|c|c|c|c|c|}
\hline 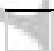 & & \multicolumn{5}{|c|}{ LMA } & \multicolumn{4}{|c|}{ Tower } & Delay & \multicolumn{3}{|c|}{ EUCLID } & \multicolumn{3}{|c|}{ Met.Station } \\
\hline \multirow{2}{*}{\multicolumn{2}{|c|}{ Event }} & \multirow{2}{*}{ hh:mm:ss } & \multirow{2}{*}{$\begin{array}{l}\text { num. } \\
\text { sourc. }\end{array}$} & \multirow{2}{*}{ first } & \multirow{2}{*}{ duration } & \multirow{2}{*}{$\begin{array}{c}\text { UPL } \\
\text { polarity }\end{array}$} & \multirow{2}{*}{$\begin{array}{l}\text { First } \\
\text { pulse }\end{array}$} & \multirow{2}{*}{$\begin{array}{l}\text { pulse } \\
\text { count }\end{array}$} & \multirow{2}{*}{\begin{tabular}{|l} 
Max \\
current
\end{tabular}} & \multirow{2}{*}{$\begin{array}{c}\text { Ave. } \\
\text { (N>2kA) }\end{array}$} & \multirow{2}{*}{$\begin{array}{l}\text { 1st LMA } \\
\text { 1st pulse }\end{array}$} & \multirow{3}{*}{$\begin{array}{l}\text { num. } \\
\text { strokes }\end{array}$} & \multirow{2}{*}{$\begin{array}{l}\text { IC/CG } \\
\text { strokes }\end{array}$} & \multirow{2}{*}{$\begin{array}{c}\text { max. peak curr } \\
\text { [stroke order] }\end{array}$} & \multirow{2}{*}{\multicolumn{2}{|c|}{ wind speed }} & \multirow{2}{*}{ w.gust } \\
\hline & & & & & & & & & & & & & & & & & \\
\hline & Date & & & $(\mathrm{s})$ & $(\mathrm{ms})$ & & $(>2 \mathrm{kA})$ & $(>2 \mathrm{kA})$ & $\mathrm{kA}$ & kA & $(\mathrm{ms})$ & & & $\mathrm{kA}$ & hh:mm & $(\mathrm{m} / \mathrm{s})$ & $(\mathrm{m} / \mathrm{s})$ \\
\hline 1 & 29-jun. & 14:02:00 & 116 & 0.4471 & 486 & positive & & -- & -- & -- & -- & -- & -- & -- & $14: 00$ & 5.8 & 11.6 \\
\hline 2 & & 14:06:12 & 51 & 12.8598 & 136 & positive & 13.2550 & 12 & -16.2 & -7.4 & 395 & 8 & $1 / 7$ & $-42.2[3]$ & $14: 10$ & 6.6 & 13.8 \\
\hline 3 & & 14:08:39 & 25 & 39.5078 & 182 & positive & 39.6891 & 18 & -17.0 & -5.6 & 181 & 18 & $11 / 7$ & $-25.1[4]$ & $14: 10$ & 6.6 & 13.8 \\
\hline 4 & & 14:11:09 & 85 & 9.3295 & 600 & positive & 9.5005 & 30 & -16.1 & -6.6 & 171 & 30 & $18 / 12$ & $-36.1[10]$ & $14: 10$ & 6.6 & 13.8 \\
\hline 5 & & $15: 05: 42$ & 18 & 42.6302 & 134 & unknown* & 42.7871 & 20 & -12.2 & -5.3 & 157 & 22 & $14 / 8$ & $-27.3[5]$ & $15: 00$ & -- & -- \\
\hline 6 & & 15:10:52 & 10 & 52.4057 & 522 & unknown* & 52.8407 & 3 & -5.5 & -4.3 & 435 & 4 & $4 / 0$ & -- & $15: 10$ & -- & -- \\
\hline 7 & & $15: 36: 49$ & 67 & 49.8095 & 573 & positive & 49.9850 & 42 & -10.6 & -5.2 & 176 & 39 & $10 / 29$ & $-31.4[15]$ & $15: 40$ & -- & -- \\
\hline 8 & & 15:39:46 & 188 & 46.2400 & 594 & positive & 46.3776 & 51 & -7.2 & -4.3 & 138 & 47 & $31 / 16$ & $-17.9[15]$ & $15: 40$ & -- & -- \\
\hline 9 & & $15: 45: 52$ & 188 & 52.1988 & 886 & positive & 52.4574 & 20 & -17.7 & -5.5 & 259 & 30 & $16 / 14$ & $-43.52[11]$ & $15: 50$ & -- & -- \\
\hline 10 & & $15: 47: 31$ & 66 & 31.3665 & 268 & positive & 31.4881 & 11 & -15.5 & -5.2 & 122 & 9 & $5 / 4$ & $-25.5[4]$ & $15: 50$ & -- & -- \\
\hline 11 & & $15: 50: 02$ & 240 & 2.0560 & 553 & positive & -- & -- & -- & -- & -- & -- & -- & -- & $15: 50$ & -- & -- \\
\hline 12 & & $15: 54: 54$ & 148 & 54.3665 & 787 & positive & 55.0674 & 20 & -14.9 & -5.9 & 701 & 18 & $8 / 10$ & -42.9 [9] & $15: 50$ & -- & -- \\
\hline 13 & 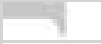 & $16: 00: 13$ & 92 & 13.4934 & 555 & positive & 13.6369 & 17 & -11.2 & -5.8 & 144 & 15 & $11 / 4$ & $-26.56[3]$ & $16: 00$ & -- & -- \\
\hline 14 & & $16: 05: 36$ & 17 & 36.7065 & 197 & unknown* & 36.8011 & 7 & -5.9 & -4.6 & 95 & 7 & $7 / 0$ & -- & $16: 00$ & -- & -- \\
\hline 15 & 10-jul. & $20: 48: 57$ & 6 & 57.7315 & 12 & unknown* & 57.8245 & 14 & -23.1 & -8.1 & 93 & 13 & $7 / 6$ & $-55.6[4]$ & $20: 50$ & 10.6 & 19.8 \\
\hline 16 & & $20: 51: 45$ & 17 & 45.0717 & 145 & positive & 45.1756 & 10 & -14.8 & -8.1 & 104 & 10 & $7 / 3$ & $-27.37[1]$ & $20: 50$ & 10.6 & 19.8 \\
\hline 17 & & 21:19:36 & 109 & 36.9912 & 164 & positive & 37.3440 & 5 & -8.7 & -5.2 & 353 & 5 & $5 / 0$ & -- & $21: 20$ & -- & -- \\
\hline 18 & 14-jul. & 13:25:39 & 20 & 39.6332 & 188 & unknown* & 39.6583 & 4 & 9.0 & -7.6 & 25 & 6 & $2 / 4$ & $-20.1[2]^{\star}$ & 13:30 & 13.0 & 19.3 \\
\hline 19 & & 14:00:12 & 84 & 12.1356 & 148 & positive & & -- & -- & -- & -- & -- & -- & -- & $14: 00$ & 10.7 & 16.9 \\
\hline
\end{tabular}

